Department of Economics- FEA/USP

\title{
ESTIMATING THE EMPLOYMENT AND \\ EDUCATIONAL EFFECTS OF VOCATIONAL TRAINING: THE ROLE OF SCHOOL QUALITY
}

\author{
CRISTIANO C. CARVALHO \\ RAPHAEL CORBI \\ RODRIGO DE-LOSSO
}

WORKING PAPER SERIES № 2021-10 
DEPARTMENT OF ECONOMICS, FEA-USP

WORKING PAPER № 2021-10

\title{
Estimating the Employment and Educational Effects of Vocational Training: the Role of School Quality
}

\author{
Cristiano C. Carvalho (crcarval@umich.edu) \\ Raphale Corbi (rcorbi@usp.br) \\ Rodrigo De-Losso (delosso@usp.br)
}

Research Group: NEFIN

\begin{abstract}
:
This paper provides new evidence of the short and long-run effects of vocational training (VT) on labor market and educational outcomes, with a particular interest in how school quality may confound estimates. VT schools may differ from regular schools not only in terms of type of training, but also in the availability of resources. We take advantage of a particular institutional arrangement in the state of Paraná, Brazil, where a single private institution named FIEP provides both VT and regular education under two separate but closely related entities, while non-FIEP institutions provide regular education. As both VT and regular schools within FIEP have more resources and better inputs than non-FIEP schools, simply comparing outcomes of VT and regular students can be misleading even if students were assigned randomly to schools. Using a unique survey applied to different cohorts of high school graduates, we show that quality plays an important but nuanced role when comparing the effects of general and VT in the short and long run. In particular, our propensity score estimates indicate that FIEP VT graduates have higher short-run employability than both FIEP and non-FIEP non-VT students. However, non-VT graduates from the better-funded FIEP system are more likely to continue to higher education, so that the short-run employment effect all but dissipates as they enter the labor force in the long-run.
\end{abstract}

Keywords: Vocational education, short and long-run labor market outcomes, higher education.

JEL Codes: C21; I25; I26; I31; J24; J31. 


\title{
Estimating the Employment and Educational Effects of Vocational Training: the Role of School Quality
}

\author{
Cristiano C. Carvalho ${ }^{\dagger} \quad$ Raphael Corbi ${ }^{\dagger \dagger} \quad$ Rodrigo De-Losso ${ }^{\dagger \dagger}$
}

March 19, 2021

\begin{abstract}
This paper provides new evidence of the short and long-run effects of vocational training (VT) on labor market and educational outcomes, with a particular interest in how school quality may confound estimates. VT schools may differ from regular schools not only in terms of type of training, but also in the availability of resources. We take advantage of a particular institutional arrangement in the state of Paraná, Brazil, where a single private institution named FIEP provides both VT and regular education under two separate but closely related entities, while non-FIEP institutions provide regular education. As both VT and regular schools within FIEP have more resources and better inputs than non-FIEP schools, simply comparing outcomes of VT and regular students can be misleading even if students were assigned randomly to schools. Using a unique survey applied to different cohorts of high school graduates, we show that quality plays an important but nuanced role when comparing the effects of general and VT in the short and long run. In particular, our propensity score estimates indicate that FIEP VT graduates have higher short-run employability than both FIEP and non-FIEP non-VT students. However, non-VT graduates from the better-funded FIEP system are more likely to continue to higher education, so that the short-run employment effect all but dissipates as they enter the labor force in the long-run.

Keywords: Vocational education, short and long-run labor market outcomes, higher education.

\footnotetext{
${ }^{\dagger}$ Corresponding author. University of Michigan. E-mail: crcarval@umich.edu

${ }^{\dagger \dagger}$ University of São Paulo. E-mail: rcorbi@usp.br

$\$$ $¥$ University of São Paulo. E-mail: delosso@usp.br
}

We are grateful to FIEP, Instituto Paraná, Renata Narita, Leonardo Rosa, and conferences and seminars participants for helpful comments. The authors acknowledge financial support from FIPE. Raphael Corbi thanks the University of Chicago for their hospitality where parts of this work were completed.
\end{abstract}




\section{Introduction}

Vocational education training has great potential for developing and improving specific skills in the workforce. The benefits of this modality are often associated with a smoother transition between school and the labor market, an increase in labor productivity and a specific labor training (Souza et al., 2015). These positive short-term effects of vocational education on income and on the likelihood of getting a job are well documented in the literature (Malamud and Pop-Eleches, 2010; Tansel, 1998; Hanushek, Woessmann, and Zhang, 2011; Almeida et al., 2015; Costa, Fernandes, and Vasconcellos, 2010; Assunção and Gonzaga, 2010; Neri, 2010).

On the other hand, the effects on wages and employment are less clear in the long-term. The rapid pace of technological change may favor skills that are more adaptable and flexible in the long-term, making the specific skills developed in the vocational training become obsolete more quickly than general skills learned in regular courses. Such trade-off brings up the question of what the effects on employment and income over an individual's life cycle are. A considerable number of papers in the literature presents evidence that the short-term effects are usually greater than the long-term and, in general, the whole cycle net effects are positive (Hanushek et al., 2017; Brunello and Rocco, 2017; Golsteyn and Stenberg, 2017; Oswald-Egg and Renold, 2021). Important exceptions are Attanasio et al. (2017) and Kugler et al. (2020) who find positive long-lasting effects of vocational training on labor market and educational outcomes in Colombia.

Another important branch of the literature analyzes the effects of vocational training on educational outcomes. The main hypothesis is that, by increasing students' motivation and engagement, vocational training reduces dropout and increase the probability of graduating from high school. Although most of the literature evidence are based on programs implemented in developed countries, some recent works that focus on developing countries provide comparable findings. For instance, Elacqua et al. (2019) find that vocational training reduces the dropout probability and increases the math and Language standardized test scores in Brazil. Importantly to our setup, they are also more likely to attend schools with better quality.

This paper contributes to this literature by uncovering new evidence of the effects of vocational training on labor market and educational outcomes, with a 
particular interest in how school quality may confound estimates. VT schools may differ from regular schools not only in terms of type of training, but also in the availability of resources. More specifically, quality improves the chance of a regular education graduate to enroll in higher education and increases the probability of a vocational training student to transit directly to the labor market in the shortterm. Therefore, it affects these two groups differently in an important channel of skill accumulation: enrollment in higher education. Hence, simply comparing vocational and non-vocational education students' outcomes may be misleading due to differences in institutional quality, even if students were assigned randomly to schools.

We take advantage of particular institutional arrangement in the state of Paraná, Brazil, where a single institution named FIEP (Paraná State Industries Federation) provides vocational and non-vocational education under two separate but closely related entities, namely SENAI (Industry's national learning service) and SESI (Industry's social service). Both entities have more resources, better teachers and infra-structure than public non-FIEP schools which provide only regular education. Our analysis compares SENAI's technical courses, designed to provide specialized skills for technical career using hands-on manufacturing training, to SESI's non-vocational high school and as well as to regular public high schools of the same areas.

Based on two unique field surveys conducted by the Paraná Research Institute, we focus on these educational modalities, SENAI and SESI, to compare the effects of the vocational and traditional courses offered by the FIEP System on the employability, wages, overall satisfaction, and enrollment in higher education. The first survey was held from August to October 2018 and captures the short-term effects by interviewing a sample of students who graduated from 2015 to 2017 . The second survey, held from May to July 2019, captures the long-term effects by interviewing a sample of students who graduated from 2011 to 2014. In both surveys, a sample of students who attend mainly the regular public high school system (not FIEP) was also interviewed. The questionnaires covered the following topics: general characteristics of the interviewees, employability and performance in the job market, satisfaction with their job, and with their professional status and educational background and enrollment in higher education. 
We proceed in two steps steps. We first select our sample by using a propensity score matching to ensure comparability between students who graduated from the FIEP System - including both vocational training and high school - and students mainly from regular public schools. ${ }^{1}$ As a second step, we use the selected sample to compare the results between FIEP and non-FIEP students, allowing for different effects between vocational and non-vocational training among the FIEP graduates. This two-step procedure allows us to (i) assess the overall effect of vocational training (usually estimated in the Brazilian literature as discussed below) by comparing outcomes of SENAI's technical students with non-FIEP graduates, as well as (ii) disentangling the overall vocational training effect due to differences in management and institutional quality and to the actual vocational aspect of training.

Our main findings show that accounting for institutional quality matters for estimating the labor market and educational effects of vocational training. Regarding short-run employability, we find that vocational training significantly increases the probability of being employed in any job and also employed in formal jobs after we control for quality. This comes at a price of decreasing the share of full-time students. Both effects still significant in the long-run but controlling for quality makes them smaller. In other words, accounting for quality has different implications over time, it increases the employment effects in the short-term, but attenuates the effects in the long-term. These estimates are consistent with students that finished high school in a better institution having a grater probability of going to higher education, decreasing their likelihood of being employed in the short-run. On the other hand, in the long-run most of them have already finished higher education and are back in the labor force.

The effects on income are also persistent over time. In both time periods, addressing the potential issue of differences in quality of the institutions has the same implications, it increases the income results of vocational training. Former students of SENAI's technical courses are more likely to be employed in higher paying jobs, both in the short- and long-run, and the effects do not seem to reduce in the long-run. When we simply compare the SENAI's technical courses former students with students who have not been enrolled in the courses offered by the

\footnotetext{
${ }^{1}$ Our main specification relies on the nearest neighbor propensity score matching with replacement. As a robustness exercise, we also use an OLS model and a kernel propensity score matching strategy
} 
FIEP System, we still find a smaller effects in the short-run, but no significant effect is found in the long-run.

Finally, the surveys include some questions that allow us to test the effects of vocational training on the satisfaction with activity sectors, professional status and educational background. After we account for quality, we find that SENAI's technical courses former students have a higher probability of being employed in the activity sector that they consider to be the most beneficial for themselves in the short-run and report lower satisfaction with their educational background both in the short and long-term. This result is also linked with the fact that vocational training students also have lower probability of enrolling in higher education in the two analyzed periods. Without addressing the potential quality issue, none of these results are observed.

We believe that comparing these two specific education modalities provide us with a complementary evidence of the vocational training effects on the labor market outcomes to the one that is provided in the literature. Attanasio, Kugler, and Meghir (2011), Attanasio et al. (2017) and Kugler et al. (2020) causally analyze the effects of large vocational program in Colombia by comparing participants with nonparticipants selected using a randomized trial. Instead of comparing participants with non-participants, we compare vocational training considering regular education as the outside option, which is an important measure to decide between public policies that focus on each of these modalities.

More precisely, the vocational program evaluated by Attanasio, Kugler, and Meghir (2011), Attanasio et al. (2017) and Kugler et al. (2020) was targeted to young people between the ages of 18 and 25, who were unemployed or out of school and who were placed in the two lowest deciles of the income distribution. By comparing participants with non-participants selected using a randomized trial, Attanasio et al. (2017) finds a positive and persistent effect in employment and earnings. Therefore, in this context, their findings indicate that vocational training can be an important safety net program to support vulnerable groups. Our paper is interested in the lifetime trade-offs of choosing vocational training over traditional education for a broader range of students, the ones that are about to complete or that have just completed high-school. The main idea is that the short-term benefits of vocational training could change future decisions about skill accumulation, such as enrollment 
in higher education.

In addition, we contribute to the existing literature on vocational training in Brazil. Past studies relied on the National Household Sample Survey (PNAD) data to measure the effects of vocational training (Almeida et al., 2015; Costa, Fernandes, and Vasconcellos, 2010; Assunção and Gonzaga, 2010; Neri, 2010). The empirical strategy consisted of using a propensity score approach on the individuals' observable characteristics, without accounting school quality due to lack of data. We address the potential issue of differences in quality across institution by taking advantage of a centralized management system. Our survey also allows us to analyze the effects for different cohorts and provide a measure of short- and long-term effects of the vocational training. Recent studies that better address the potential omitted variables bias using experimental analysis do not make the distinction between time period frames, and, therefore, provide no answers about the vocational training effects over time (Camargo et al., 2018).

Our estimates also provide a relevant input for policy design in a moment when vocational training has been gaining relevance in the country. In the recent years Brazil has increased significantly the amount invested in vocational education. The Federal Government expenditure has increased 5 times from 2003 to 2016 (0.04\% to $0.2 \%$ ) and the number of students enrolled in technical education during high school increased by $45 \%$ between 2007 and 2013 (Elacqua et al., 2019). Vocational training is offered by public and private institutions in Brazil. A major role is played by the entities such as FIEP System across most other states, which are private institutions partially financed with public resources. They are privately managed but they are allowed to collect mandatory taxes on the payroll of firms in their activity sector. Their main purpose is to provide technical and vocational training to address the specific demands of skilled labor in their activity sectors.

This paper is organized into 5 sections beyond this Introduction. The following section briefly describes the institutional background behind the FIEP education system. Section 3 presents in detail the database and the methodology used in this paper. Sections 4 and 5 present the results of participation in FIEP System courses and robustness checks, respectively. Finally, section 6 concludes this paper. 


\section{Institutional Background: the FIEP Educational System}

In Brazil, the vocational education training courses are offered by public and private institutions. Even though, public institutions enroll more students than private ones, a significant part of the technical and vocational education is provided by the entities that constitute the so-called S System (private institutions partially financed with public resources.): provide $43 \%$ of professional and technical education in Brazil (Souza et al., 2015).

The S system is composed of a group of private and nonprofit entities classified as autonomous social service. Those entities are sector specific and have two main goals: i) to improve the quality of life of workers in each sector covered, ii) to provide technical and vocational education to meet the demand for skilled work in their respective sectors. The S System as a whole has 10 entities in total, namely: SENAI, SESI, IEL, SENAC, SESC, SEBRAE, SENAR, SENAT/SEST, and SESCOOP. The entities are privately managed, but they are allowed to collect mandatory taxes on the payroll of firms in their activity sector. (Souza et al., 2015)

The structure of the $\mathrm{S}$ system varies across states in Brazil. In the state of Paraná, some entities that integrate the S System, more specifically the Industry's national learning service (SENAI) and the Industry's social service (SESI), work collaboratively with the entity that represents the industrial business category (FIEP - Paraná State Industries Federation). Those entities together constitute the FIEP System. The advantage of having this sort of integration between the S System and the entity that represents the industrial business category is to be able to offer vocational courses that will address specific needs of the market.

This article focuses on two specific courses offered by the FIEP Educational System: SENAI's technical courses, and SESI's high school course. Those modalities can be divided in vocational and traditional education, since SENAI's courses are designed to prepare and train their students in specialized skills for specific career fields using hands-on training on industry, and SESI's high school focuses on broader theory. The technical courses that we evaluate in this paper are not integrated in the high school, they either require the student to be enrolled in (concomitant) or have finished (subsequent) high school, but they do not offer it jointly with their 
vocational training ${ }^{2}$. It is also worth noting that even thought SESI's high school is more focused on broader theory, their students receive discounts in case they enroll in a SENAI's course.

It is important to highlight that private high-schools are widely recognized in Brazil by their average superior quality. Therefore, comparing vocational training, that is often privately provided, with students that have not been enrolled in the FIEP system could lead to misleading results, since participation in vocational training would be confounded with better inputs. Table 1 presents the average results in ENEM, a standardized exam required to enroll in higher education, and the mean difference test between the SESI high-school and public and private school in Paraná. The descriptive results presented in table 1 provides some evidence that SESI high-schools have on average a better performance in standard exams than public schools and a worse performance than private schools. Unfortunately, these variables are not available to SENAI, since we are focusing on concomitant and subsequent courses, and we have to rely on the hypothesis that the quality inputs might not significantly differ between SESI and SENAI since they are centrally managed by the same institution. We also present some infrastructure measures in the appendix (tables A1 and A2) that show that SESI high schools usually have better infrastructure than public high schools. In terms of infrastructure, although SENAI technical courses are not significantly different from public institutions that offer this same modality, they also have better structure than public regular schools.

\section{$3 \quad$ Data and identification strategy}

\subsection{Data}

The field research conducted by the Paraná Research Institute was designed to estimate the effects of the courses offered by the FIEP System on the employability, wages, overall satisfaction of its graduating students, and enrollemnt in higher enducation. Data was collected in two complementary rounds. In the first of them, students graduated from the courses between the years of 2015 to 2017 and students who have not been enrolled in the courses offered by the FIEP System were

\footnotetext{
${ }^{2}$ The SENAI's courses that we analyze in this paper are not integrated to the regular high school. They require the student to be enrolled or have completed the high school, but students independently choose the institutions to take high school and vocational training.
} 
interviewed from August to October 2018. This first sample covers 813 students from SENAI's technical courses, 523 from SESI high school and 873 students from outside the FIEP System and is used to measure the short-term effects of vocational training offered by the FIEP System. In the second round, students graduated from the courses in the years of 2011 to 2014 and students who have not been enrolled in the courses offered by the FIEP System were interviewed from May to July 2019. Overall, 731 students from SENAI's technical courses, 1375 from SESI high school and 167 students from outside the FIEP System were interviewed in order to complement the first round and provide measures for the long-term effects of participating in the System's technical courses.

The sample of interviewed students was selected using the stratified sampling technique, which consists of dividing the entire population into different subgroups so that each individual is part of only one stratum. After defining the subgroups, the selection of respondents can be performed by simple random sampling within each defined stratum. The strata are defined according to characteristics observed for the entire population, ensuring the complete representativeness of those characteristics in the selected sample and reducing the sampling error. It is worth noting that the selection process of the interviewees followed the same script in both stages, but was carried out independently.

In this context, we first use the stratified sampling technique to ensure that the sample of graduated students are representative of the population of graduate students from the covered years, 2011 to 2017. Second, we use this technique to select the sample of students who have not been enrolled in the courses offered by the FIEP System and to ensure it presents similar characteristics to the sample of graduate students. We use two data sources to implement this technique, namely: the administrative data of all students who graduated from the courses provided by FIEP, and the Paraná Research Institute database covering information of a broader sample, people who have not been enrolled in the FIEP System.

Based on the information available at the Paraná Research Institute database ${ }^{3}$,

\footnotetext{
${ }^{3}$ The variables available at the Paraná Research Database are: Sex (Male/Female), Age brackets (16-24 years old/25-34 years old/35 or older), Schooling (Elementary School (Complete or Incomplete)/High School (Complete or Incomplete)/Higher Education (Complete or Incomplete), Main Occupation (Registered Employee/Unregistered Employee/Public Employee/Selfemployed (registered)/Self-employed/Entrepreneur/Free-lancer/Intern/Apprentice (Paid)/ Unemployed (Job Seeker)/ Inactive (Not a Job Seeker)/Housewife/Retired/Only student/ Only living
} 
we selected the students that are outsiders from the FIEP System in 3 steps:

1. All observations with the following main occupations were excluded: Public Employee, only housewife, only retired or only living of some income. Additionally, individuals who earned more than 10 minimum wages of monthly household income were excluded.

2. Based on remaining population we kept only individuals with complete or incomplete high school, and complete or incomplete higher education, which were representative of SESI high school, SENAI technical and qualification courses.

3. Within the remaining subsample, the strata were defined according to the age group, the gender and the subregion of the state of Parana in a way that replicates each stratum observed in the group of students graduated from the courses offered by FIEP.

The sampling strategy presented above was also used when selecting the sample of students that graduated from FIEP courses with a small difference, the subsample was subdivided into two subgroups: SESI high school and SENAI technical courses. We implemented this additional step to preserve the representativeness of these two courses separately.

The questionnaire answered by the interviewees contained questions that covered the following topics: general characteristics of the interviewees, employability and performance in the job market, satisfaction with their job, and with their professional status and educational background and enrollment in higher education. All questions included in the questionnaire were multiple choice. The full version of the questionnaire is presented in the annex.

\subsection{Identification Strategy}

In order to assess causality, we first need to ensure that the sample of students who have not been enrolled in the courses offered by the FIEP System is similar to

of some income), Monthly household income (Up to 1 minimum wage (mw)/Between 2 and 5 mws/Between 6 and 10 mws/ More than 10 mws) and City. 
sample of students who graduated from these courses. We partially address this issue in the survey sample selection by using the stratified randomization. We further ensure comparability using the propensity score matching technique, the most common way to choose individuals with similar characteristics between different groups. Based on observable characteristics relevant to the selection of program participants, we select one or more units in the group of outsiders that are as similar as possible to each unit in the group of graduates of the FIEP System courses.

The main issue that matching and other impact assessment methods try to solve is the problem of selection bias in the participation of a given program. That is, it is possible for program participants to be previously different from non-participants. In this case, simply measuring the results between groups would be capturing prior differences and not just the effect of participation in a particular program. Formally, matching is based on the following identification hypothesis: conditional on some covariate vector $X$, the outcome $Y$ is independent of $D$, where $D \in\{0,1\}$ is a dummy variable of participation in FIEP courses. It is noteworthy that matching on $\mathrm{X}$ is problematic if this vector is of high dimension ("curse of dimensionality").

To address this dimensionality problem, we prefer to use the propensity score matching method. When the probability of participating in a program depends on several observable factors, rather than selecting similar individuals based on a multidimensional measure, it is possible to establish a one-dimensional measure for such a process (balancing score). This measure is given by the propensity score, which is the probability of participation in the program conditional on covariates, that is, the predicted probability of participation of individuals given their set of observed characteristics. Rosenbaum and Rubin (1983) and Dehejia and Wahba (1998) present the formal proof that allows the transformation of a multidimensional measure into the propensity score.

The basic idea of the matching method is to search in a large group of nonparticipants those individuals who are similar to the participants group in all relevant observable characteristics. The selection bias is eliminated in the process as long as it only occurs in the observable characteristics included in the model. In order words, we must assume that the conditional hypothesis is valid, which means there can be no unobservable characteristics that are associated at the same time with program participation and potential outcomes. Formally based on Heckman, Ichimura, and 
Todd (1997), where Y (0) is the potential results of non-participants in the courses offered by FIEP, we should assume:

$$
\mathrm{Y}(0) \perp \mathrm{D} \mid \mathrm{P}(\mathrm{X})
$$

Therefore, the non-participant outcomes have, conditional on $\mathrm{P}(\mathrm{X})$, the same distribution that participants would have experienced if they had not participated in the program.

In addition, the common support hypothesis should be valid, that is, although observable characteristics may influence the likelihood of participating in a program, participation cannot be completely defined by a set of variables. This hypothesis ensures that it is possible to find an individual in the control group for each individual in the treatment group after controlling for the influence of covariates. We should assume:

$$
\operatorname{Pr}(\mathrm{D}=1 \mid X)<1 \forall \mathrm{X}
$$

Our dataset contains a rich set of socio-demographic variables. We assume that they can potentially influence the participation in the courses and the labor market and matching quality outcomes. Therefore, the variables incorporated in the vector X were: education level, geographic region of the state of Paraná, gender, age group, marital status, family condition (if the person is responsible for the household), a dummy variable if the individual attended young adult education, and a dummy variable if the person attended public school. The long-term survey asks the individuals in retrospect about their employment status and income when they started taking the course. We add this information as control variables for this specific sample. In addition to the variables used in stratified randomization, we ensure that the outsiders' group is similar to the group that took a course in the FIEP System also in these characteristics included in the model.

We use the propensity score estimates to select the closest neighbor of each individual in the sample of students who graduated from all the courses offered by FIEP $^{4}$. After estimating the participation probability using a Probit model, we allow

\footnotetext{
${ }^{4}$ We run the propensity score considering all FIEP courses together to obtain the nearest neighbor in the outsiders' group. After obtaining the nearest neighbor, we allow for different coefficients for students who graduated from SESI high school and from SENAI's technical course, and are able to test between them.
} 
for replacement in the selection process, i.e., the same individual in the outsiders' group can be selected as counterfactual for more than one individual in the FIEP System group. To guarantee that we are selecting similar individuals, a caliper of 2p.p. is used - 2p.p. is the maximum level of tolerance for the distance between the individual's propensity score in the two groups considered. If the tolerance level is exceeded, such individual in the FIEP System group is not considered in the estimation.

After the final sample is defined, we compare the average of the outcome variable weighting for how many times the same individual in the outsiders group was used as counterfactual and also allowing for different effects of vocational training and high school among the FIEP System graduates ${ }^{5}$. This strategy permits us to have two different control groups at the end - SESI high school and outsiders - to measure the effects of SENAI vocational training. We expect that, by comparing SENAI's technical former students with students from outside the FIEP System, we will have a measure similar to the one that is commonly used in the Brazilian literature, that is totally based on the conditional on observable variables exogeneity hypothesis. A more flexible measure is obtained by comparing SENAI's technical former students with students that graduated from SESI high school. We believe that this measure of vocational training effect better addresses the potential issue of differences in management and quality of the institutions that provide those two different education modalities, since both courses are provided and managed by the same institution - the FIEP System.

It is worth noting that, even though we believe that our estimation strategy allows us to control for some unobservable variables, such as differences in quality and management of the institutions, our results are still in some measure dependent on the hypothesis that the selection into the groups must be determined by observable characteristics. We rely on the assumption that no other unobservable characteristic is driving the choice between high school and vocational training for the students that decide to enroll in a course provided by the FIEP System. Additionally, the difference in the results when using each of the control groups would only reflect the effects of quality if no other omitted variable is affecting the selection into the FIEP System courses. Based on that assumptions, our main specification relies on

\footnotetext{
${ }^{5}$ According to Caliendo and Kopeinig (2006), the use of the nearest neighbor with replacement is the method that minimizes bias but has a high variance.
} 
the nearest neighbor propensity score matching with replacement. As a robustness exercise, we also use an OLS model and a kernel propensity score matching.

Figure 1 presents the density function of the probability of participating in the courses. It is possible to observe that the common support hypothesis is respected. For all different probability of participation (x-axis), it is possible to observe some mass in the density function for both groups. Moreover, the weighting performed after selecting the nearest neighbor makes the density functions similar, in other words, for each probability of participation the same mass of people is observed.

Figure 1: Density function of probability of participating in courses

Short run
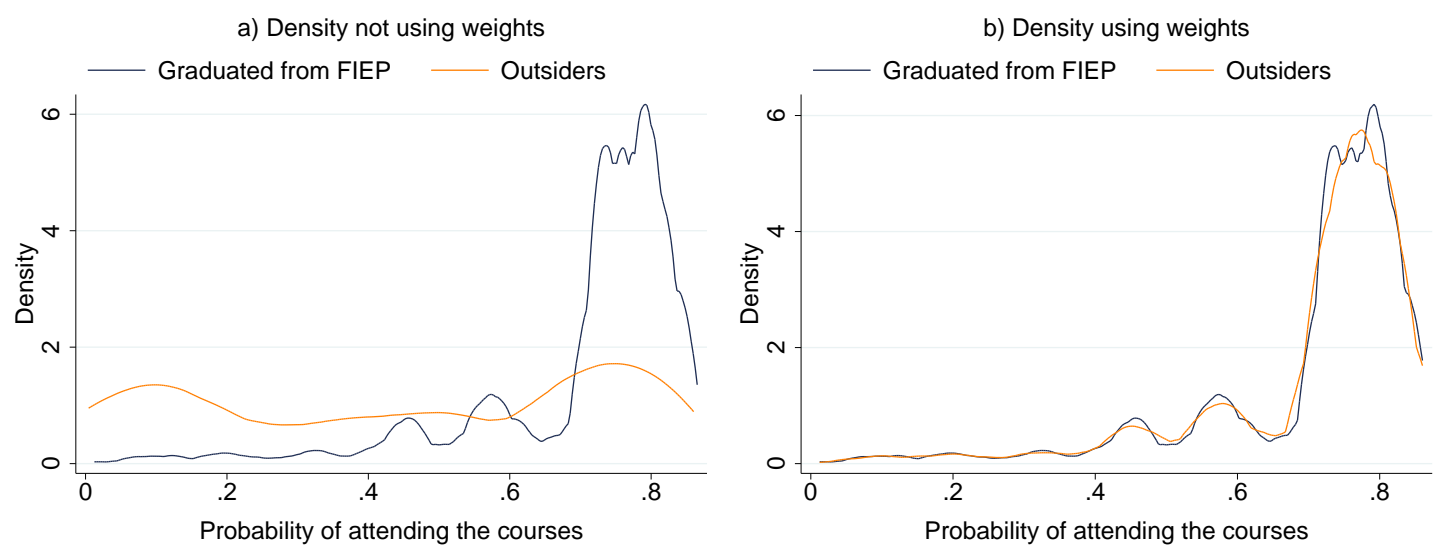

Long run
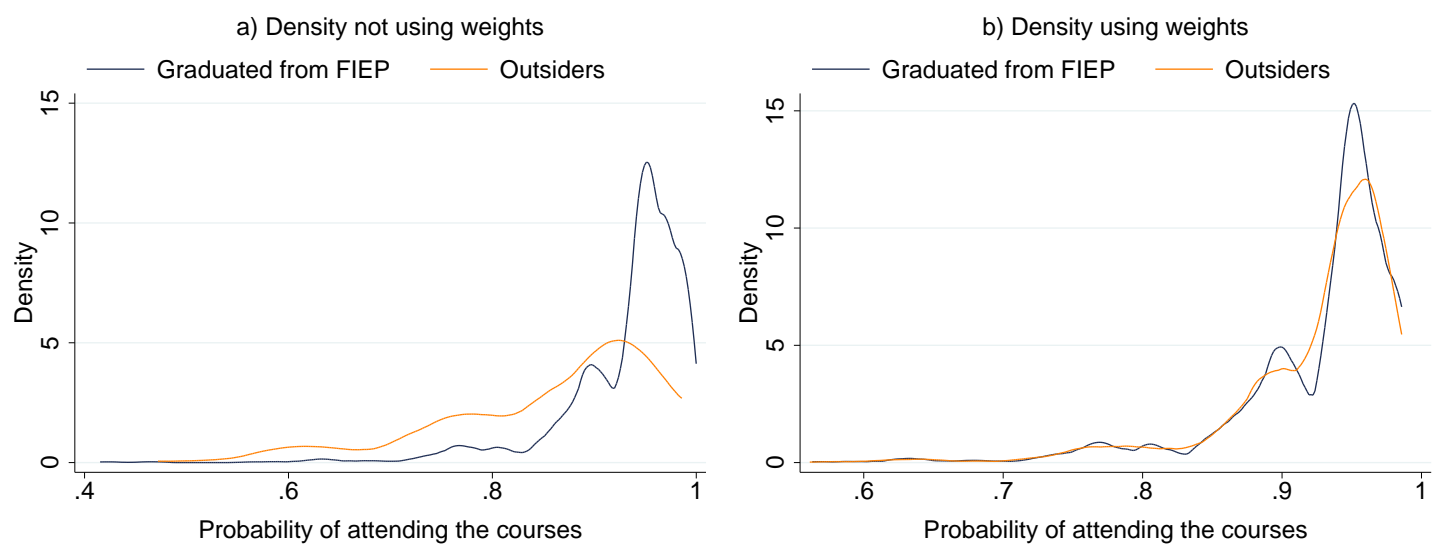

\subsection{Difference in the average tests}

The main purpose of the matching method is to ensure that the groups analyzed are comparable to each other in their observable characteristics. To test if this was 
achieved, we test the difference between the average of the variables in each of the analyzed groups for both periods, short and long-term. We present the average tests for the total sample of respondents and for the sample that is selected by the matching method. Results are shown in the table 2. The "Difference" column presents the results of the statistical tests that verify if the differences in the average between the groups are significant.

Analyzing the table 2, it is possible to verify that the matching method corrects almost all pre-existing differences in the socio-demographic variables, ensuring comparability between the groups in the short-term. In the long-term, the matching does not correct all the differences due to the small sample of outsiders. It is noteworthy that stratified randomization was performed based on the variables of age, gender and region of the state of Paraná. However, it is not possible to guarantee that there are no differences between the groups in the other variables. The matching method was performed with the inclusion of all variables presented in the table 2, and, as presented, it makes the groups more comparable in all these dimensions.

\section{Results}

The effects of vocational training on the variables that measure employment status, income, overall satisfaction, and enrollment in higher education are presented below. We compare the short and long-term effects of each course covered in our analysis. In the tables, we report the average of the dependent variable for the control group, consisted of students outside the FIEP System, and the difference between them and the two groups of students graduated from the FIEP System - regular and vocational education. In order to present a measure that accounts for difference in institutions' quality, we also present the p-value of a $T$ test for the difference between the coefficients estimated for students that graduated from vocational and regular FIEP courses.

The effects of the vocational training on the professional status are presented in table 3. An important finding is that controlling for quality has an important impact on the vocational training results for most variables. More specifically, if we simply compare the students graduated from the SENAI technical courses with the students that are outsiders, we find positive significant effects only on employment in 
the formal sector (23.3p.p.) in the short-run and on general employment (18.5p.p.) and on employment in the formal sector (18.1p.p.) in the long-run.

More nuanced results are found when we test the estimated coefficients between the students graduated from SENAI technical courses and SESI high school. The employment effects become even more pronounced in the short-run. We find that the former students of SENAI technical courses are 24p.p. $\quad(=0.0942+0.1466)$ more likely to be employed and 25.6p.p $(=0.2331+0.0232)$ more likely to be employed in the formal sector in comparison to the students graduated from the SESI high school, with both differences significant at a $1 \%$ significance level. A higher employment probability comes at a price of decreasing the share dedicated to only study in this group. A SENAI graduate is 23p.p. (=-0.0631 - 0.1673) less likely to be only studying in the short-run relatively to a SESI high school graduate.

Differently from the short-run, controlling for quality attenuates all effects in the long-run, but they are still significant. The former students of the SENAI technical courses are 4.4p.p. $(=0.1856$ - 0.1408) more likely to be employed and 9p.p $(=0.1815-0.0917)$ more likely to be employed in the formal sector in comparison to the students graduated from the SESI high school. The difference in the share that is only studying persists in the long-run, a SENAI graduate is 4.2p.p. $(=-0.0906+$ 0.0487) less likely to be only studying in the long-run relatively to a SESI high school graduate. A possible rationale for why accounting for institutions quality intensifies the effects on the short-run and diminishes the effects on long-run is that students that took regular education from high quality institutions have a higher chance of going to college, and, as a consequence, to stay out of the labor force until they complete their studies. In the long-run, when they return to the labor force, they catch up part of the difference in the probability of being employed in comparison to the students that graduated from vocational training.

The effects on income are also influenced by accounting for potential differences in quality between educational institutions. Different from the pattern observed when analyzing the employment status variable, controlling for quality accentuates the positive effects of a vocational training in the short- and in the long-run. As presented in table 4, by comparing the students who graduated from the SENAI technical courses with the students that are outsiders, we find positive and significant effects on income in the short-run, vocational training former students are 16.9p.p. 
more likely to earn more than $\mathrm{R} \$ 2000.00$. However, this positive effect on income totally fade out in the long-run.

The same is not true when we test the estimated coefficients between the students graduated from SENAI technical courses and SESI high school. The difference in the income distribution between these two groups continues significant in the long-run. In the short-run, the SENAI technical courses former students are 28.7p.p. $(=0.1698+0.1169)$ and 4.2p.p. $(=0.0251+0.0165)$ more likely to earn more than $\mathrm{R} \$ 2000.00$ and more than $\mathrm{R} \$ 4000.00$, respectively. In the long-run, these differences change to 22.3p.p. $(=0.0397+0.1832)$ and 6.5p.p. $(=-0.0457+0.1111)$ and still significant at a $1 \%$ significance level. A possible rationale for these results is that a higher employment inflow among the SESI high school graduates are also associated with an increase in the share of the inexperienced workers in this group, driving the income distribution towards low paying jobs.

In order to get a complete picture of the effects of vocational training, we measure the former students' satisfaction with their activity sectors, professional status and educational background. More specifically, we use different dummy variables that indicate if the individual is employed in their preferred activity sector, and if they are satisfied with their professional status and with their education background. The results are presented in the first three columns of table 5. The effects are not very informative when quality is not taken into account. Comparing SENAI technical graduates with the group of outsiders, we find significant effects only on the share that is satisfied with their professional status in the long-run (15.2p.p.).

A more consistent analysis is provided when we account for institutions' quality. By comparing the SENAI technical courses and SESI high school, we find that the SENAI technical graduates are more likely to be employed in their preferred activity sector $(12$ p.p. $\quad(=0.1180+0.0019))$, but are relatively less likely to be satisfied with their educational background (-6.6p.p. $(=0.1339-0.2008))$ in the short-run. In the long-run, only the negative effect in the satisfaction with the educational background persists. More precisely, the SENAI technical course former student is 6.7 p.p. $(=0.0209-0.0877)$ less likely to be satisfied with their educational background.

Finally, the effects of vocational training on the probability of enrolling in higher 
education (bachelors' degree and postgraduate education) are presented in the fourth column of table 5. The results are consistent with the argument that controlling for institution quality increases the chance of going to college among the students that took regular education from high quality institutions (SESI high school). As presented in the table, no effect in enrollment is found when we compared the SENAI technical graduates with the group of students that are outsiders. However, relatively to the SESI high school graduates, a SENAI technical course former student is less likely to be enrolled in higher education in the short- $(-16.2 p . p . \quad(=-0.0491$ - 0.1129)) and long-run (-16p.p. (=-0.0129 - 0.1470)). In summary, the better employment outcomes comes at a price of a lower enrollment in higher education.

\section{Robustness checks}

In this section we check the robustness of our results by re-estimating them using two alternative econometric specifications: 1) we use an Epanechnikov kernel propensity score matching procedure; 2) We run an OLS model using the same vector of control variables that we use in the matching process.

It is important to highlight that exists a trade-off between bias and variance among the propensity score models that we use in this paper. On one hand, the Epanechnikov kernel matching increases the number of distinct non-participants used to construct the counterfactual outcome and therefore decreases the variance of the estimator. On the other hand, this non-parametric method uses the whole distribution of individuals which likely decreases the average quality of matching and increase the bias, especially in the case where the propensity score distribution is very different in the treatment and control group (Caliendo and Kopeinig, 2008). To partially address this problem, we also impose the same caliper used when estimating the nearest neighbor method, 2p.p. No relation, however, can be stated when comparing OLS and propensity score method in terms of bias and variance.

The results using these two alternative methods are presented in tables 6 to 8 . The main results found on the employment status variables are maintained in our robustness analysis. Vocational training courses increase the probability of being generally employed and employed in the formal sector both in the short- and long-

run. By controlling for institutions' quality, the employment effects become more 
pronounced in the short-run and diminishes in the long-run. Importantly, in the short-run a higher employment probability comes at a price of decreasing the share dedicated to only study for the group of vocational training graduates. The degree of attenuation in the long-run effects, however, varies with the estimation method. When the results are estimated using a propensity score matching approach, the effect on employment decreases, but still significant in the long-run. In the results estimated using OLS, no difference between regular and vocational training graduates persists in the long-run. Similarly, in both cases, ignoring the institution quality dimension leads to an overestimation of vocational training long-run effects on employment.

The effects on income are also consistent across all different estimation methods. Similarly to what is found in our main specification, controlling for quality accentuates the positive effects of a vocational training in the short- and in the long-run. Comparing the students who graduated from SENAI technical courses and SESI high school, we find that the former is more likely to be employed in a higher paying job both in the short- and long-run. The effects found using OLS are smaller than the ones estimated using propensity score methods, but they are also significant at $1 \%$ significance level.

Finally, the effects on the satisfaction variables and on the probability of enrolling in higher education are consistent between the different propensity score matching methods, but differ from the results estimated using OLS. The estimates of the Epanechnikov kernel matching approach also show that the SENAI technical graduates are more likely to be employed in their preferred activity sector, but are relatively less likely to be satisfied with their educational background in the short-run, and, in the long-run, only the latter effect persists. Regarding the higher education enrollment, using this method we find that the vocational training graduates are less likely to be enrolled in short- and long-run. These effects, however, are sensible to the estimation method. Using a OLS, the only effect that persists is the greater activity sector satisfaction of vocational training graduates in the short-run. 


\section{Conclusion}

This paper provides evidence about the short- and long-term effects of vocational training on employment status, income, overall satisfaction, and enrollment in higher education. We take advantage of particular institutional arrangement in the state of Paraná, Brazil, where a single private institution named FIEP provides both vocational and regular education under two separate but closely related entities, while non-FIEP institutions provide regular education. As both vocational and regular schools within FIEP have more resources, better teachers and infra-structure than non-FIEP schools, simply comparing outcomes of vocational training and regular students can be misleading even if students were assigned randomly to schools.

Using a unique survey applied to different cohorts of high school graduates, we show that quality plays an important but nuanced role when comparing the effects of general and vocational education in the short and long run. In particular, our propensity score estimates indicate that FIEP vocational training graduates have higher short-run employability than both FIEP and non-FIEP regular students. However, regular graduates from the better-funded FIEP system are more likely to continue to higher education, so that the short-run employment effect all but dissipates as they enter the labor force in the long-run. We also find that vocational training has a persistent positive effect on income both in the short and long-run, especially when accounting for differences in quality.

Our estimates provide a relevant input for policy design in a moment when vocational training has been gaining relevance in Brazil. In recent years, Federal Government expenditure has increased 5 times from 2003 to 2016 (0.04\% to $0.2 \%)$ and the number of students enrolled in technical education during high school increased by $45 \%$ between 2007 and 2013 (Elacqua et al., 2019). Industrial associations such as FIEP play a major role in providing vocational education across Brazilian regions. While privately managed, they are mainly funded via payroll tax revenues. Hence understanding the effectiveness of such publicly-funded type of enterprises is key to improving human capital in Brazil. 


\section{References}

Almeida, Rita, Anazawa, Leandro, Menezes Filho, Naercio, and Vasconsellos, Ligia (2015). "Investing in Technical Vocational Education and Training: Does It Yield Large Economic Returns in Brazil?" World Bank WPS7246.

Assunção, J and Gonzaga, G. (2010). "Educação Profissional no Brasil: Inserção e Retorno."

Attanasio, Orazio, Guarín, Arlen, Medina, Carlos, and Meghir, Costas (2017). "Vocational Training for Disadvantaged Youth in Colombia: A Long-Term FollowUp". American Economic Journal: Applied Economics 9, pp. 131-143.

Attanasio, Orazio, Kugler, Adriana, and Meghir, Costas (2011). "Subsidizing Vocational Training for Disadvantaged Youth in Colombia: Evidence from a Randomized Trial". American Economic Journal: Applied Economics 3, 188-220.

Brunello, G. and Rocco, L. (2017). "The labour market effects of vocational and academic education over the life cycle. Evidence based on a British cohort." Journal of Human Capital 11.2, pp. 106-166.

Caliendo, M. and Kopeinig, S. (2008). "Some Practical Guidance for the Implementation of Propensity Score Matching." Journal of Economic Surveys 22.1, pp. $31-72$.

Caliendo, Marco and Kopeinig, Sabine (2006). Some practical guidance for the implementation of propensity score matching. Tech. rep. Institute for the Study of Labor (IZA).

Camargo, Juliana, Lima, Lycia, Riva, Flavio, and Souza, André Portela (2018) (2018). "Technical education, noncognitive skills and labor market outcomes: experimental evidence from Brazil." Textos para discussão 480, FGV/EESP Escola de Economia de São Paulo, Getulio Vargas Foundation (Brazil).

Costa, Fernanda, Fernandes, Julia Guerra, and Vasconcellos, Lígia (2010). "Avaliação Econômica do Ensino Médio Profissional." Fundação Itaú Social.

Dehejia, R. H. and Wahba, S. (1998). "Propensity score matching methods for nonexperimental causal studies." NBER working paper 6829.

Elacqua, Gregory, Navarro-Palau, Patricia, Fernanda Prada, Maria, and Soares, Sammara (2019). "Does technical education improve academic outcomes? Evidence from Brazil." IDB working paper IDB-WP-01057. 
Golsteyn, B. H. H. and Stenberg, A. (2017). "Earnings over the life course: General versus vocational education." Journal of Human Capital 11.2, pp. 167-212.

Hanushek, E. A., Schwerdt, G., Woessmann, L., and Zhang, L. (2017). "General education, vocational education, and labor-market outcomes over the lifecycle." Journal of Human Resources 52.1, pp. 58-87.

Hanushek, Eric A., Woessmann, Ludger, and Zhang, Lei. (2011). "General education, vocational education, and labor-market outcomes over the life-cycle." National Bureau of Economic Research w17504.

Heckman, J., Ichimura, H., and Todd, P. (1997). "Matching as an Econometric Evaluation Estimator: Evidence from Evaluating a Job Training Programme." Review of Economic Studies 64, 605-654.

Kugler, Adriana, Kugler, Maurice, Saavedra, Juan E., and Herrera-Pradas, Luis Omar (2020). "Long-Term Educational Consequences of Vocational Training in Colombia: Impacts on Young Trainees and their Relatives". Journal of Human Resources.

Malamud, Ofer and Pop-Eleches, Cristian (2010). "General education versus vocational training: Evidence from an economy in transition." Review of Economics and Statistics 92.1, pp. 43-63.

Neri, Marcelo (2010). "A Educação Profissional e Você no Mercado de Trabalho". Rio de Janeiro: FGV/CPS.

Oswald-Egg, Maria Esther and Renold, Ursula (2021). "No experience, no employment: The effect of vocational education and training work experience on labour market outcomes after higher education". Economics of Education Review 80, p. 102065.

Rosenbaum, P. R. and Rubin, D. B. (1983). "The central role of the propensity score in observational studies for causal effects." Biometrika 70.1, pp. 41-55.

Souza, Andre Portela, Lima, Lycia, Arabage, Amanda, Camargo, Juliana, Lucena, Thiago de, and Soares, Sammara (2015). Vocational Education and Training in Brazil. Tech. rep. Inter-American Development Bank.

Tansel, Aysit (1998). "General versus vocational high schools and labor market outcomes in Turkey". Economic Research Forum Working Paper 9905. 
Table 1: Difference in the average ENEM (2015) variables between Sesi and other high schools

\begin{tabular}{lcccccccc}
\hline & \multicolumn{2}{c}{$\begin{array}{c}\text { Public Paraná } \\
(1)\end{array}$} & $\begin{array}{c}\text { Private Paraná } \\
(2)\end{array}$ & \multicolumn{2}{c}{$\begin{array}{c}\text { Sesi } \\
(3)\end{array}$} & \multicolumn{2}{c}{ Testing the mean differences } \\
\cline { 2 - 9 } & Mean & Obs & Mean & Obs & Mean & Obs & $(1)-(3)$ & $(2)-(3)$ \\
\hline Participation rate & 62.2881 & 391 & 84.1577 & 273 & 83.6944 & 45 & $-21.4063^{* * *}$ & 0.4632 \\
Average in natural science & 478.3771 & 391 & 539.3789 & 273 & 493.3822 & 45 & $-15.0052^{* * *}$ & $45.9966^{* * *}$ \\
Average in human science & 559.7686 & 391 & 605.9794 & 273 & 575.0084 & 45 & $-15.2399^{* * *}$ & $30.9709^{* * *}$ \\
Average in Portuguese & 506.0876 & 391 & 555.1439 & 273 & 523.2969 & 45 & $-17.2092^{* * *}$ & $31.8470^{* * *}$ \\
Average in math & 469.9187 & 391 & 557.967 & 273 & 500.5831 & 45 & $-30.6644^{* * *}$ & $57.3839^{* * *}$ \\
Average in writing & 534.2359 & 391 & 612.7274 & 273 & 564.8487 & 45 & $-30.6127^{* * *}$ & $47.8788^{* * *}$ \\
Index of faculty adequacy & 78.5803 & 390 & 68.1136 & 272 & 75.4667 & 45 & $3.1136^{*}$ & $-7.3531^{* * *}$ \\
Student permanence index in high school & 82.8856 & 391 & 68.9434 & 273 & 75.6313 & 45 & $7.2542^{* * *}$ & $-6.6880^{*}$ \\
Students' approval rate in high school & 83.8453 & 391 & 96.1187 & 273 & 97.3119 & 42 & $-13.4666^{* * *}$ & $-1.1932^{* *}$ \\
Students' failure rate in high school & 10.1936 & 391 & 3.7264 & 273 & 2.4214 & 42 & $7.7722^{* * *}$ & $1.3049^{* *}$ \\
Students' dropout rate in high school & 5.9611 & 391 & 0.1549 & 273 & 0.2667 & 42 & $5.6945^{* * *}$ & -0.1117 \\
\hline
\end{tabular}

Significance levels: $* 10 \%, * * 5 \%, * * * 1 \%$. 
Table 2: Difference in the average tests between treatment and control groups

\begin{tabular}{|c|c|c|c|c|c|c|}
\hline & \multicolumn{3}{|c|}{ Without matching } & \multicolumn{3}{|c|}{ With matching } \\
\hline & $\begin{array}{l}\text { Graduated from } \\
\text { FIEP }\end{array}$ & Outsiders & Difference & $\begin{array}{l}\text { Graduated from } \\
\text { FIEP }\end{array}$ & Outsiders & Difference \\
\hline \multicolumn{7}{|l|}{ Short-term } \\
\hline \multicolumn{7}{|l|}{ Age group } \\
\hline $16-24$ years old & 0.8024 & 0.52 & $0.2823^{* * *}$ & 0.8018 & 0.8011 & 0.0008 \\
\hline $25-34$ years old & 0.1243 & 0.2096 & $-0.0854^{* * *}$ & 0.1246 & 0.1186 & 0.006 \\
\hline 35 or older & 0.0734 & 0.2703 & $-0.1970^{* * *}$ & 0.0736 & 0.0803 & -0.0068 \\
\hline Share of females & 0.3787 & 0.37 & 0.0088 & 0.3799 & 0.3836 & -0.0038 \\
\hline \multicolumn{7}{|l|}{ Geographic region of the State of Paraná } \\
\hline Central & 0.0689 & 0.0664 & 0.0024 & 0.0691 & 0.0503 & 0.0188 \\
\hline Curitiba & 0.4057 & 0.362 & $0.0437^{* *}$ & 0.4047 & 0.4122 & -0.0075 \\
\hline North & 0.357 & 0.362 & -0.0049 & 0.3574 & 0.3761 & -0.0188 \\
\hline West & 0.0876 & 0.1031 & -0.0155 & 0.0878 & 0.0743 & 0.0135 \\
\hline South & 0.0808 & 0.1065 & $-0.0257^{* *}$ & 0.0811 & 0.0871 & -0.006 \\
\hline \multicolumn{7}{|l|}{ Education level } \\
\hline Elementary School (complete or incomplete) & 0.0037 & 0.0435 & $-0.0398^{* * *}$ & 0.0038 & 0.0015 & 0.0023 \\
\hline High school (complete or incomplete) & 0.5479 & 0.5888 & $-0.0409^{*}$ & 0.5495 & 0.5375 & 0.012 \\
\hline Higher education (complete or incomplete) & 0.4416 & 0.3379 & $0.1037^{* * *}$ & 0.4399 & 0.458 & -0.018 \\
\hline Postgraduate studies & 0.0067 & 0.0298 & $-0.0230^{* * *}$ & 0.0068 & 0.003 & 0.0038 \\
\hline Share that attended regular school & 0.9386 & 0.89 & $0.0486^{* * *}$ & 0.9392 & 0.9542 & -0.015 \\
\hline $\begin{array}{l}\text { Share that attended public school } \\
\text { Marital status }\end{array}$ & 0.7418 & 0.8396 & $-0.0979^{* * *}$ & 0.744 & 0.7372 & 0.0068 \\
\hline Single & 0.8361 & 0.606 & $0.2301^{* * *}$ & 0.8356 & 0.8378 & -0.0023 \\
\hline Married & 0.1557 & 0.3414 & $-0.1857 * * *$ & 0.1562 & 0.1532 & 0.003 \\
\hline Share responsible for the household & 0.2313 & 0.4147 & $-0.1834^{* * *}$ & 0.2297 & 0.2095 & 0.0203 \\
\hline Observations & 1336 & 873 & 2209 & 1332 & 184 & 1516 \\
\hline \multicolumn{7}{|l|}{ Long-term } \\
\hline \multicolumn{7}{|l|}{ Age group } \\
\hline $16-24$ years old & 0.8884 & 0.8982 & -0.0098 & 0.9191 & 0.9656 & $-0.0465^{* * *}$ \\
\hline $25-34$ years old & 0.0693 & 0.024 & $0.0454^{* *}$ & 0.0349 & 0.0079 & $0.0270^{* * *}$ \\
\hline 35 or older & 0.0423 & 0.0778 & $-0.0356^{* *}$ & 0.046 & 0.0264 & $0.0196^{* *}$ \\
\hline Share of females & 0.3941 & 0.4072 & -0.0131 & 0.4209 & 0.4807 & $-0.0598^{* * *}$ \\
\hline \multicolumn{7}{|l|}{ Geographic region of the State of Paraná } \\
\hline Central & 0.1662 & 0.1737 & -0.0075 & 0.1777 & 0.2031 & -0.0254 \\
\hline Curitiba & 0.4858 & 0.4371 & 0.0486 & 0.458 & 0.4659 & -0.0079 \\
\hline North & 0.2251 & 0.2036 & 0.0215 & 0.2348 & 0.221 & 0.0137 \\
\hline West & 0.0665 & 0.1198 & $-0.0533^{* * *}$ & 0.0693 & 0.0693 & 0 \\
\hline South & 0.0565 & 0.0659 & -0.0094 & 0.0603 & 0.0407 & $0.0196^{* *}$ \\
\hline \multicolumn{7}{|l|}{ Education level } \\
\hline Elementary School (complete or incomplete) & 0 & 0 & 0 & 0 & 0 & 0 \\
\hline High school (complete or incomplete) & 0.2213 & 0.3593 & $-0.1380^{* * *}$ & 0.2285 & 0.1645 & $0.0640^{* * *}$ \\
\hline Higher education (complete or incomplete) & 0.7179 & 0.5389 & $0.1790^{* * *}$ & 0.7076 & 0.7795 & $-0.0719^{* * *}$ \\
\hline Postgraduate studies & 0.0608 & 0.1018 & $-0.0410^{* *}$ & 0.064 & 0.0561 & 0.0079 \\
\hline Share that attended regular school & 0.9691 & 0.9341 & $0.0350^{* *}$ & 0.9693 & 0.9741 & -0.0048 \\
\hline Share that attended public school & 0.6918 & 0.8683 & $-0.1764^{* * *}$ & 0.7308 & 0.7604 & -0.0296 \\
\hline \multicolumn{7}{|l|}{ Marital status } \\
\hline Single & 0.7612 & 0.7365 & 0.0246 & 0.7816 & 0.8123 & $-0.0307^{*}$ \\
\hline Married & 0.226 & 0.2395 & -0.0135 & 0.2052 & 0.1803 & 0.0249 \\
\hline Share responsible for the household & 0.2702 & 0.3234 & -0.0532 & 0.2681 & 0.2411 & 0.027 \\
\hline Observations & 2106 & 167 & 2273 & 1891 & 125 & 2016 \\
\hline
\end{tabular}


Table 3: Effect of each course on employment status variables

\begin{tabular}{|c|c|c|c|c|c|}
\hline & $\begin{array}{c}(1) \\
\text { Unemployed }\end{array}$ & $\begin{array}{c}(2) \\
\text { Inactive }\end{array}$ & $\begin{array}{c}(3) \\
\text { Studying }\end{array}$ & $\begin{array}{c}(4) \\
\text { Employed }\end{array}$ & $\begin{array}{c}\text { (5) } \\
\text { Employed in a } \\
\text { formal job }\end{array}$ \\
\hline \multicolumn{6}{|l|}{ Short-term Effects } \\
\hline Senai technical & $\begin{array}{c}0.0052 \\
(0.0745)\end{array}$ & $\begin{array}{c}-0.0152 \\
(0.0202)\end{array}$ & $\begin{array}{c}-0.0631 \\
(0.0691)\end{array}$ & $\begin{array}{c}0.0942 \\
(0.0827)\end{array}$ & $\begin{array}{c}0.2331^{* * *} \\
(0.0642)\end{array}$ \\
\hline Sesi high-school & $\begin{array}{c}0.0187 \\
(0.0751)\end{array}$ & $\begin{array}{c}-0.0204 \\
(0.0204)\end{array}$ & $\begin{array}{l}0.1673^{* *} \\
(0.0711)\end{array}$ & $\begin{array}{c}-0.1466^{*} \\
(0.0839)\end{array}$ & $\begin{array}{c}-0.0232 \\
(0.0644)\end{array}$ \\
\hline Mean dep. var - control group & 0.1329 & 0.0473 & 0.2357 & 0.5631 & 0.2477 \\
\hline Coeff. equality test ( $\mathrm{T}$ test - p-value) & 0.496 & 0.582 & 0.000 & 0.000 & 0.000 \\
\hline Observations & 1516 & 1516 & 1516 & 1516 & 1516 \\
\hline \multicolumn{6}{|l|}{ Long-term Effects } \\
\hline Senai technical & $\begin{array}{c}-0.0943 \\
(0.0609)\end{array}$ & $\begin{array}{l}-0.0019 \\
(0.0109)\end{array}$ & $\begin{array}{c}-0.0906 \\
(0.0638)\end{array}$ & $\begin{array}{l}0.1856^{* *} \\
(0.0757)\end{array}$ & $\begin{array}{l}0.1815^{* *} \\
(0.0728)\end{array}$ \\
\hline Sesi high-school & $\begin{array}{l}-0.0862 \\
(0.0604)\end{array}$ & $\begin{array}{l}-0.0085 \\
(0.0102)\end{array}$ & $\begin{array}{l}-0.0487 \\
(0.0636)\end{array}$ & $\begin{array}{l}0.1408^{*} \\
(0.0750)\end{array}$ & $\begin{array}{c}0.0917 \\
(0.0714)\end{array}$ \\
\hline Mean dep. var - control group & 0.1750 & 0.0132 & 0.1713 & 0.6351 & 0.3548 \\
\hline Coeff. equality test ( $\mathrm{T}$ test - p-value) & 0.552 & 0.158 & 0.003 & 0.021 & 0.000 \\
\hline Observations & 2016 & 2016 & 2016 & 2016 & 2016 \\
\hline \multicolumn{6}{|c|}{$\begin{array}{l}\text { Significance levels: } * 10 \%, * * 5 \%, * * * 1 \% \text {. We use robust standard errors. The table presents the results using employment status variables } \\
\text { in the short and long-term. The columns display the results for different binary variables, and also the shares observed in the control group } \\
\text { consisted of outsiders. We first select our sample using the propensity score method. We select the closest neighbor of each individual by } \\
\text { estimating the participation probability using a Probit model, we allow for replacement in the selection process, i.e., the same individual } \\
\text { in the control group can be selected as counterfactual for more than one individual in the treatment group. To guarantee that we are } \\
\text { selecting similar individuals, a caliper of } 2 \text { p.p. is used - 2p.p. is the maximum level of tolerance for the distance between the individual's } \\
\text { propensity score in the treatment group and their nearest neighbor in the control group. If the tolerance level is exceeded, such individual } \\
\text { in the treatment group is not considered in the estimation. After the final sample is defined, we estimate by OLS the difference between } \\
\text { the groups in terms of the average outcome variable weighting for how many times the same individual in the control group was used as } \\
\text { counterfactual. We build the confidence intervals using robust standard errors. }\end{array}$} \\
\hline
\end{tabular}


Table 4: Effect of each course on different income brackets

\begin{tabular}{|c|c|c|c|}
\hline & $\begin{array}{c}(1) \\
\text { Less than } \mathrm{R} \$ 2.000\end{array}$ & $\begin{array}{c}(2) \\
\text { More than } \mathrm{R} \$ 2.001\end{array}$ & $\begin{array}{c}(3) \\
\text { More than } \mathrm{R} \$ 4.001\end{array}$ \\
\hline \multicolumn{4}{|l|}{ Short-term Effects } \\
\hline Senai technical & $\begin{array}{c}-0.1698^{* * *} \\
(0.0561)\end{array}$ & $\begin{array}{c}0.1698^{* * *} \\
(0.0561)\end{array}$ & $\begin{array}{c}0.0251^{*} \\
(0.0148)\end{array}$ \\
\hline Sesi high-school & $\begin{array}{l}0.1169^{* *} \\
(0.0551)\end{array}$ & $\begin{array}{c}-0.1169^{* *} \\
(0.0551)\end{array}$ & $\begin{array}{l}-0.0165 \\
(0.0136)\end{array}$ \\
\hline Mean dep. var - control group & 0.8062 & 0.1938 & 0.0310 \\
\hline Coeff. equality test ( $\mathrm{T}$ test - p-value) & 0.000 & 0.000 & 0.002 \\
\hline Observations & 844 & 844 & 844 \\
\hline \multicolumn{4}{|l|}{ Long-term Effects } \\
\hline Senai technical & $\begin{array}{l}-0.0397 \\
(0.0923)\end{array}$ & $\begin{array}{c}0.0397 \\
(0.0923)\end{array}$ & $\begin{array}{l}-0.0457 \\
(0.0878)\end{array}$ \\
\hline Sesi high-school & $\begin{array}{l}0.1832^{* *} \\
(0.0908)\end{array}$ & $\begin{array}{c}-0.1832^{* *} \\
(0.0908)\end{array}$ & $\begin{array}{l}-0.1111 \\
(0.0868)\end{array}$ \\
\hline Mean dep. var - control group & 0.4874 & 0.5126 & 0.1817 \\
\hline Coeff. equality test ( $\mathrm{T}$ test - p-value) & 0.000 & 0.000 & 0.000 \\
\hline Observations & 1498 & 1498 & 1498 \\
\hline \multicolumn{4}{|c|}{$\begin{array}{l}\text { Significance levels: } * 10 \%, * * 5 \%, * * * 1 \% \text {. We use robust standard errors. The table presents the results using income bracket variables in } \\
\text { the short and long-term. The columns display the results for different binary variables, and also the shares observed in the control group } \\
\text { consisted of outsiders. We first select our sample using the propensity score method. We select the closest neighbor of each individual by } \\
\text { estimating the participation probability using a Probit model, we allow for replacement in the selection process, i.e., the same individual } \\
\text { in the control group can be selected as counterfactual for more than one individual in the treatment group. To guarantee that we are } \\
\text { selecting similar individuals, a caliper of 2p.p. is used - 2p.p. is the maximum level of tolerance for the distance between the individual's } \\
\text { propensity score in the treatment group and their nearest neighbor in the control group. If the tolerance level is exceeded, such individual } \\
\text { in the treatment group is not considered in the estimation. After the final sample is defined, we estimate by OLS the difference between } \\
\text { the groups in terms of the average outcome variable weighting for how many times the same individual in the control group was used as } \\
\text { counterfactual. We build the confidence intervals using robust standard errors. }\end{array}$} \\
\hline
\end{tabular}


Table 5: Effects of the courses on the share of satisfaction variables

\begin{tabular}{|c|c|c|c|c|}
\hline & $\begin{array}{c}\text { (1) } \\
\text { Activity } \\
\text { Sector }\end{array}$ & $\begin{array}{c}(2) \\
\text { Professional } \\
\text { Status } \\
\end{array}$ & $\begin{array}{c}(3) \\
\text { Education } \\
\text { Background }\end{array}$ & $\begin{array}{c}\text { (4) } \\
\text { Enrolled in } \\
\text { Higher Education }\end{array}$ \\
\hline \multicolumn{5}{|l|}{ Short-term Effects } \\
\hline \multirow[t]{2}{*}{ Senai technical } & 0.1180 & 0.1014 & $0.1339^{*}$ & -0.0491 \\
\hline & $(0.1026)$ & $(0.0851)$ & $(0.0739)$ & $(0.0817)$ \\
\hline \multirow[t]{2}{*}{ Sesi high-school } & -0.0019 & 0.0741 & $0.2008^{* * *}$ & 0.1129 \\
\hline & $(0.1059)$ & $(0.0860)$ & $(0.0740)$ & $(0.0828)$ \\
\hline Mean dep. var - control group & 0.4739 & 0.6564 & 0.6935 & 0.4437 \\
\hline Coeff. equality test ( $\mathrm{T}$ test - p-value) & 0.003 & 0.271 & 0.000 & 0.000 \\
\hline Observations & 853 & 1497 & 1514 & 1516 \\
\hline \multicolumn{5}{|l|}{ Long-term Effects } \\
\hline \multirow[t]{2}{*}{ Senai technical } & 0.0409 & $0.1520^{* *}$ & 0.0209 & -0.0129 \\
\hline & $(0.0894)$ & $(0.0771)$ & $(0.0652)$ & $(0.0724)$ \\
\hline \multirow[t]{2}{*}{ Sesi high-school } & 0.0262 & 0.1126 & 0.0877 & $0.1470^{* *}$ \\
\hline & $(0.0881)$ & $(0.0762)$ & $(0.0640)$ & $(0.0712)$ \\
\hline Mean dep. var - control group & 0.5595 & 0.6098 & 0.8070 & 0.3538 \\
\hline Coeff. equality test ( $T$ test - p-value) & 0.586 & 0.065 & 0.000 & 0.000 \\
\hline Observations & 1572 & 2004 & 2013 & 2016 \\
\hline \multicolumn{5}{|c|}{$\begin{array}{l}\text { Significance levels: } * 10 \%, * * 5 \%, * * * 1 \% \text {. We use robust standard errors. The columns display the results for different binary } \\
\text { variables, and also the shares observed in the control group consisted of outsiders. "Activity Sector" is a dummy variable that } \\
\text { indicates if the individuals are employed in their preferred activity sector. "Professional Status" and "Educational Background" are } \\
\text { dummies that equal } 1 \text { if the individuals are satisfied with their professional status and with their education background, respectively, } \\
\text { "Enrolled in Higher Education" is a dummy variable that indicates if someone is enrolled in higher education, such as bachelors' } \\
\text { degree or postgraduate education. We first select our sample using the propensity score method. We select the closest neighbor of } \\
\text { each individual by estimating the participation probability using a Probit model, we allow for replacement in the selection process, } \\
\text { i.e., the same individual in the control group can be selected as counterfactual for more than one individual in the treatment group. } \\
\text { To guarantee that we are selecting similar individuals, a caliper of } 2 \text { p.p. is used - 2p.p. is the maximum level of tolerance for the } \\
\text { distance between the individual's propensity score in the treatment group and their nearest neighbor in the control group. If the } \\
\text { tolerance level is exceeded, such individual in the treatment group is not considered in the estimation. After the final sample is } \\
\text { defined, we estimate by OLS the difference between the groups in terms of the average outcome variable weighting for how many } \\
\text { times the same individual in the control group was used as counterfactual. We build the confidence intervals using robust standard } \\
\text { errors. }\end{array}$} \\
\hline
\end{tabular}


Table 6: Effect of each course on employment status variables

\begin{tabular}{|c|c|c|c|c|c|}
\hline & $\begin{array}{c}(1) \\
\text { Unemployed }\end{array}$ & $\begin{array}{c}(2) \\
\text { Inactive }\end{array}$ & $\begin{array}{c}(3) \\
\text { Studying }\end{array}$ & $\begin{array}{c}(4) \\
\text { Employed }\end{array}$ & $\begin{array}{c}\text { (5) } \\
\text { Employed in a } \\
\text { formal job }\end{array}$ \\
\hline \multicolumn{6}{|l|}{$\begin{array}{l}\text { Short-term Effects } \\
\text { PSM w / replacement (baseline) }\end{array}$} \\
\hline Senai technical & $\begin{array}{c}0.0052 \\
(0.0745)\end{array}$ & $\begin{array}{l}-0.0152 \\
(0.0202)\end{array}$ & $\begin{array}{l}-0.0631 \\
(0.0691)\end{array}$ & $\begin{array}{c}0.0942 \\
(0.0827)\end{array}$ & $\begin{array}{r}0.2331^{* * *} \\
(0.0642)\end{array}$ \\
\hline Sesi high-school & $\begin{array}{c}0.0187 \\
(0.0751)\end{array}$ & $\begin{array}{l}-0.0204 \\
(0.0204)\end{array}$ & $\begin{array}{l}0.1673^{* *} \\
(0.0711)\end{array}$ & $\begin{array}{l}-0.1466^{*} \\
(0.0839)\end{array}$ & $\begin{array}{l}-0.0232 \\
(0.0644)\end{array}$ \\
\hline Mean dep. var - control group & 0.1329 & 0.0473 & 0.2357 & 0.5631 & 0.2477 \\
\hline Coeff. equality test ( $\mathrm{T}$ test - p-value) & 0.496 & 0.582 & 0.000 & 0.000 & 0.000 \\
\hline Observations & 1516 & 1516 & 1516 & 1516 & 1516 \\
\hline \multicolumn{6}{|l|}{ PSM Epanechnikov kernel } \\
\hline Senai technical & $\begin{array}{c}0.0075 \\
(0.0197)\end{array}$ & $\begin{array}{c}-0.0270^{* *} \\
(0.0121)\end{array}$ & $\begin{array}{l}-0.0392 \\
(0.0248)\end{array}$ & $\begin{array}{c}0.0762^{* * *} \\
(0.0289)\end{array}$ & $\begin{array}{c}0.1687^{* * *} \\
(0.0282)\end{array}$ \\
\hline Sesi high-school & $\begin{array}{c}0.0210 \\
(0.0221)\end{array}$ & $\begin{array}{c}-0.0322^{* *} \\
(0.0126)\end{array}$ & $\begin{array}{c}0.1912^{* * *} \\
(0.0300)\end{array}$ & $\begin{array}{c}-0.1645^{* * *} \\
(0.0320)\end{array}$ & $\begin{array}{c}-0.0876^{* * *} \\
(0.0286)\end{array}$ \\
\hline Mean dep. var - control group & 0.1306 & 0.0591 & 0.2119 & 0.5810 & 0.3122 \\
\hline Coeff. equality test ( $\mathrm{T}$ test - p-value) & 0.496 & 0.582 & 0.000 & 0.000 & 0.000 \\
\hline Observations & 2205 & 2205 & 2205 & 2205 & 2205 \\
\hline \multicolumn{6}{|l|}{ OLS } \\
\hline Senai technical & $\begin{array}{c}0.0111 \\
(0.0177)\end{array}$ & $\begin{array}{c}-0.0317^{* * *} \\
(0.0120)\end{array}$ & $\begin{array}{c}0.0020 \\
(0.0181)\end{array}$ & $\begin{array}{l}0.0551^{* *} \\
(0.0241)\end{array}$ & $\begin{array}{c}0.1668^{* * *} \\
(0.0247)\end{array}$ \\
\hline Sesi high-school & $\begin{array}{c}0.0020 \\
(0.0224)\end{array}$ & $\begin{array}{c}-0.0371^{* * *} \\
(0.0131)\end{array}$ & $\begin{array}{c}0.1225^{* * *} \\
(0.0280)\end{array}$ & $\begin{array}{c}-0.0642^{* *} \\
(0.0309)\end{array}$ & $\begin{array}{c}0.0224 \\
(0.0281)\end{array}$ \\
\hline Mean dep. var - control group & 0.1203 & 0.0905 & 0.1329 & 0.5968 & 0.2910 \\
\hline Coeff. equality test ( $\mathrm{T}$ test $-\mathrm{p}$-value) & 0.663 & 0.615 & 0.000 & 0.000 & 0.000 \\
\hline Observations & 2209 & 2209 & 2209 & 2209 & 2209 \\
\hline \multicolumn{6}{|l|}{$\begin{array}{l}\text { Long-term Effects } \\
\text { PSM w/ replacement (baseline) }\end{array}$} \\
\hline Senai technical & $\begin{array}{l}-0.0943 \\
(0.0609)\end{array}$ & $\begin{array}{l}-0.0019 \\
(0.0109)\end{array}$ & $\begin{array}{l}-0.0906 \\
(0.0638)\end{array}$ & $\begin{array}{l}0.1856^{* *} \\
(0.0757)\end{array}$ & $\begin{array}{l}0.1815^{* *} \\
(0.0728)\end{array}$ \\
\hline Sesi high-school & $\begin{array}{l}-0.0862 \\
(0.0604)\end{array}$ & $\begin{array}{l}-0.0085 \\
(0.0102)\end{array}$ & $\begin{array}{l}-0.0487 \\
(0.0636)\end{array}$ & $\begin{array}{c}0.1408^{*} \\
(0.0750)\end{array}$ & $\begin{array}{c}0.0917 \\
(0.0714)\end{array}$ \\
\hline Mean dep. var - control group & 0.1750 & 0.0132 & 0.1713 & 0.6351 & 0.3548 \\
\hline Coeff. equality test ( $\mathrm{T}$ test - p-value) & 0.552 & 0.158 & 0.003 & 0.021 & 0.000 \\
\hline Observations & 2016 & 2016 & 2016 & 2016 & 2016 \\
\hline \multicolumn{6}{|l|}{ PSM Epanechnikov kernel } \\
\hline Senai technical & $\begin{array}{l}-0.0368 \\
(0.0311)\end{array}$ & $\begin{array}{l}-0.0060 \\
(0.0129)\end{array}$ & $\begin{array}{c}-0.1153^{* * *} \\
(0.0415)\end{array}$ & $\begin{array}{c}0.1615^{* * *} \\
(0.0479)\end{array}$ & $\begin{array}{c}0.1519^{* * *} \\
(0.0500)\end{array}$ \\
\hline Sesi high-school & $\begin{array}{l}-0.0288 \\
(0.0302)\end{array}$ & $\begin{array}{l}-0.0126 \\
(0.0123)\end{array}$ & $\begin{array}{c}-0.0734^{*} \\
(0.0411)\end{array}$ & $\begin{array}{l}0.1168^{* *} \\
(0.0468)\end{array}$ & $\begin{array}{c}0.0621 \\
(0.0478)\end{array}$ \\
\hline Mean dep. var - control group & 0.1176 & 0.0173 & 0.1961 & 0.6591 & 0.3845 \\
\hline Coeff. equality test ( $\mathrm{T}$ test $-\mathrm{p}$-value) & 0.552 & 0.158 & 0.003 & 0.021 & 0.000 \\
\hline Observations & 2057 & 2057 & 2057 & 2057 & 2057 \\
\hline \multicolumn{6}{|l|}{ OLS } \\
\hline Senai technical & $\begin{array}{l}-0.0364 \\
(0.0288)\end{array}$ & $\begin{array}{l}-0.0052 \\
(0.0125)\end{array}$ & $\begin{array}{c}-0.0534^{* *} \\
(0.0267)\end{array}$ & $\begin{array}{c}0.1166^{* * *} \\
(0.0387)\end{array}$ & $\begin{array}{c}0.1180^{* * *} \\
(0.0431)\end{array}$ \\
\hline Sesi high-school & $\begin{array}{l}-0.0353 \\
(0.0270)\end{array}$ & $\begin{array}{l}-0.0139 \\
(0.0101)\end{array}$ & $\begin{array}{c}-0.0619^{* *} \\
(0.0262)\end{array}$ & $\begin{array}{c}0.1245^{* * *} \\
(0.0366)\end{array}$ & $\begin{array}{l}0.0887^{* *} \\
(0.0408)\end{array}$ \\
\hline Mean dep. var - control group & 0.1257 & 0.0180 & 0.1257 & 0.7006 & 0.3952 \\
\hline Coeff. equality test ( $\mathrm{T}$ test - $\mathrm{p}$-value) & 0.946 & 0.178 & 0.603 & 0.719 & 0.270 \\
\hline Observations & 2273 & 2273 & 2273 & 2273 & 2273 \\
\hline
\end{tabular}


Table 7: Effect of each course on different income brackets

\begin{tabular}{|c|c|c|c|}
\hline & $\begin{array}{c}(1) \\
\text { Less than } \mathrm{R} \$ 2.000\end{array}$ & $\begin{array}{c}(2) \\
\text { More than } \mathrm{R} \$ 2.001\end{array}$ & $\begin{array}{c}(3) \\
\text { More than } \mathrm{R} \$ 4.001\end{array}$ \\
\hline \multicolumn{4}{|l|}{ Short-term Effects } \\
\hline Senai technical & $\begin{array}{c}-0.1698^{* * *} \\
(0.0561)\end{array}$ & $\begin{array}{c}0.1698^{* * *} \\
(0.0561)\end{array}$ & $\begin{array}{c}0.0251^{*} \\
(0.0148)\end{array}$ \\
\hline Sesi high-school & $\begin{array}{l}0.1169^{* *} \\
(0.0551)\end{array}$ & $\begin{array}{c}-0.1169^{* *} \\
(0.0551)\end{array}$ & $\begin{array}{l}-0.0165 \\
(0.0136)\end{array}$ \\
\hline Mean dep. var - control group & 0.8062 & 0.1938 & 0.0310 \\
\hline Coeff. equality test ( $\mathrm{T}$ test - p-value) & 0.000 & 0.000 & 0.002 \\
\hline Observations & 844 & 844 & 844 \\
\hline \multicolumn{4}{|l|}{ PSM Epanechnikov kernel } \\
\hline Senai technical & $\begin{array}{c}-0.1647^{* * *} \\
(0.0307)\end{array}$ & $\begin{array}{c}0.1647^{* * *} \\
(0.0307)\end{array}$ & $\begin{array}{c}0.0181 \\
(0.0132)\end{array}$ \\
\hline Sesi high-school & $\begin{array}{c}0.1220^{* * *} \\
(0.0289)\end{array}$ & $\begin{array}{c}-0.1220^{* * *} \\
(0.0289)\end{array}$ & $\begin{array}{c}-0.0235^{* *} \\
(0.0118)\end{array}$ \\
\hline Mean dep. var - control group & 0.8011 & 0.1989 & 0.0380 \\
\hline Coeff. equality test ( $\mathrm{T}$ test - p-value) & 0.000 & 0.000 & 0.001 \\
\hline Observations & 1219 & 1219 & 1219 \\
\hline \multicolumn{4}{|l|}{ OLS } \\
\hline Senai technical & $\begin{array}{c}-0.0621^{* *} \\
(0.0283)\end{array}$ & $\begin{array}{l}0.0621^{* *} \\
(0.0283)\end{array}$ & $\begin{array}{l}-0.0226 \\
(0.0165)\end{array}$ \\
\hline Sesi high-school & $\begin{array}{c}0.0057 \\
(0.0301)\end{array}$ & $\begin{array}{l}-0.0057 \\
(0.0301)\end{array}$ & $\begin{array}{l}-0.0074 \\
(0.0148)\end{array}$ \\
\hline Mean dep. var - control group & 0.6498 & 0.3502 & 0.1134 \\
\hline Coeff. equality test ( $\mathrm{T}$ test - p-value) & 0.012 & 0.012 & 0.247 \\
\hline Observations & 1222 & 1222 & 1222 \\
\hline \multicolumn{4}{|l|}{ Long-term Effects } \\
\hline Senai technical & $\begin{array}{l}-0.0397 \\
(0.0923)\end{array}$ & $\begin{array}{c}0.0397 \\
(0.0923)\end{array}$ & $\begin{array}{l}-0.0457 \\
(0.0878)\end{array}$ \\
\hline Sesi high-school & $\begin{array}{l}0.1832^{* *} \\
(0.0908)\end{array}$ & $\begin{array}{c}-0.1832^{* *} \\
(0.0908)\end{array}$ & $\begin{array}{l}-0.1111 \\
(0.0868)\end{array}$ \\
\hline Mean dep. var - control group & 0.4874 & 0.5126 & 0.1817 \\
\hline Coeff. equality test ( $T$ test - p-value) & 0.000 & 0.000 & 0.000 \\
\hline Observations & 1498 & 1498 & 1498 \\
\hline \multicolumn{4}{|l|}{ PSM Epanechnikov kernel } \\
\hline Senai technical & $\begin{array}{l}-0.0929 \\
(0.0636)\end{array}$ & $\begin{array}{c}0.0929 \\
(0.0636)\end{array}$ & $\begin{array}{l}-0.0094 \\
(0.0462)\end{array}$ \\
\hline Sesi high-school & $\begin{array}{l}0.1300^{* *} \\
(0.0613)\end{array}$ & $\begin{array}{c}-0.1300^{* *} \\
(0.0613)\end{array}$ & $\begin{array}{c}-0.0748^{*} \\
(0.0443)\end{array}$ \\
\hline Mean dep. var - control group & 0.5405 & 0.4595 & 0.1454 \\
\hline Coeff. equality test ( $\mathrm{T}$ test - p-value) & 0.000 & 0.000 & 0.000 \\
\hline Observations & 1522 & 1522 & 1522 \\
\hline \multicolumn{4}{|l|}{ OLS } \\
\hline Senai technical & $\begin{array}{l}-0.0815 \\
(0.0509)\end{array}$ & $\begin{array}{c}0.0815 \\
(0.0509)\end{array}$ & $\begin{array}{l}-0.0141 \\
(0.0365)\end{array}$ \\
\hline Sesi high-school & $\begin{array}{c}0.0037 \\
(0.0478)\end{array}$ & $\begin{array}{l}-0.0037 \\
(0.0478)\end{array}$ & $\begin{array}{l}-0.0153 \\
(0.0333)\end{array}$ \\
\hline Mean dep. var - control group & 0.6055 & 0.3945 & 0.1193 \\
\hline Coeff. equality test ( $\mathrm{T}$ test - p-value) & 0.004 & 0.004 & 0.944 \\
\hline Observations & 1681 & 1681 & 1681 \\
\hline
\end{tabular}


Table 8: Effects of the courses on the share of satisfaction variables

\begin{tabular}{|c|c|c|c|c|}
\hline & $\begin{array}{c}\text { (1) } \\
\text { Activity } \\
\text { Sector }\end{array}$ & $\begin{array}{c}(2) \\
\text { Professional } \\
\text { Status }\end{array}$ & $\begin{array}{c}(3) \\
\text { Education } \\
\text { Background }\end{array}$ & $\begin{array}{c}(4) \\
\text { Enrolled in } \\
\text { Higher Education }\end{array}$ \\
\hline \multicolumn{5}{|l|}{ Short-term Effects } \\
\hline Senai technical & $\begin{array}{c}0.1180 \\
(0.1026)\end{array}$ & $\begin{array}{c}0.1014 \\
(0.0851)\end{array}$ & $\begin{array}{c}0.1339^{*} \\
(0.0739)\end{array}$ & $\begin{array}{l}-0.0491 \\
(0.0817)\end{array}$ \\
\hline Sesi high-school & $\begin{array}{l}-0.0019 \\
(0.1059)\end{array}$ & $\begin{array}{c}0.0741 \\
(0.0860)\end{array}$ & $\begin{array}{c}0.2008^{* * *} \\
(0.0740)\end{array}$ & $\begin{array}{c}0.1129 \\
(0.0828)\end{array}$ \\
\hline Mean dep. var - control group & 0.4739 & 0.6564 & 0.6935 & 0.4437 \\
\hline Coeff. equality test ( $\mathrm{T}$ test - p-value) & 0.003 & 0.271 & 0.000 & 0.000 \\
\hline Observations & 853 & 1497 & 1514 & 1516 \\
\hline \multicolumn{5}{|l|}{ PSM Epanechnikov kernel } \\
\hline Senai technical & $\begin{array}{c}0.1646^{* * *} \\
(0.0376)\end{array}$ & $\begin{array}{c}0.0941^{* * *} \\
(0.0273)\end{array}$ & $\begin{array}{c}0.1413^{* * *} \\
(0.0257)\end{array}$ & $\begin{array}{c}0.0086 \\
(0.0298)\end{array}$ \\
\hline Sesi high-school & $\begin{array}{c}0.0447 \\
(0.0460)\end{array}$ & $\begin{array}{l}0.0668^{* *} \\
(0.0300)\end{array}$ & $\begin{array}{c}0.2081^{* * *} \\
(0.0258)\end{array}$ & $\begin{array}{c}0.1706^{* * *} \\
(0.0327)\end{array}$ \\
\hline Mean dep. var - control group & 0.4273 & 0.6637 & 0.6861 & 0.3860 \\
\hline Coeff. equality test ( $\mathrm{T}$ test - p-value) & 0.003 & 0.271 & 0.000 & 0.000 \\
\hline Observations & 1229 & 2170 & 2200 & 2205 \\
\hline \multicolumn{5}{|l|}{ OLS } \\
\hline Senai technical & $\begin{array}{c}0.1291^{* * *} \\
(0.0339)\end{array}$ & $\begin{array}{c}0.0890^{* * *} \\
(0.0243)\end{array}$ & $\begin{array}{c}0.1411^{* * *} \\
(0.0231)\end{array}$ & $\begin{array}{c}0.0638^{* * *} \\
(0.0163)\end{array}$ \\
\hline Sesi high-school & $\begin{array}{c}0.0539 \\
(0.0470)\end{array}$ & $\begin{array}{c}0.0826^{* * *} \\
(0.0298)\end{array}$ & $\begin{array}{c}0.1559^{* * *} \\
(0.0250)\end{array}$ & $\begin{array}{c}0.0651^{* * *} \\
(0.0190)\end{array}$ \\
\hline Mean dep. var - control group & 0.4659 & 0.6565 & 0.6847 & 0.1993 \\
\hline Coeff. equality test ( $\mathrm{T}$ test - p-value) & 0.092 & 0.812 & 0.440 & 0.938 \\
\hline Observations & 1231 & 2173 & 2204 & 2209 \\
\hline \multicolumn{4}{|l|}{ Long-term Effects } & PSM w/ replacement (baseline) \\
\hline Senai technical & $\begin{array}{c}0.0409 \\
(0.0894)\end{array}$ & $\begin{array}{l}0.1520^{* *} \\
(0.0771)\end{array}$ & $\begin{array}{c}0.0209 \\
(0.0652)\end{array}$ & $\begin{array}{l}-0.0129 \\
(0.0724)\end{array}$ \\
\hline Sesi high-school & $\begin{array}{c}0.0262 \\
(0.0881)\end{array}$ & $\begin{array}{c}0.1126 \\
(0.0762)\end{array}$ & $\begin{array}{c}0.0877 \\
(0.0640)\end{array}$ & $\begin{array}{l}0.1470^{* *} \\
(0.0712)\end{array}$ \\
\hline Mean dep. var - control group & 0.5595 & 0.6098 & 0.8070 & 0.3538 \\
\hline Coeff. equality test ( $\mathrm{T}$ test - p-value) & 0.586 & 0.065 & 0.000 & 0.000 \\
\hline Observations & 1572 & 2004 & 2013 & 2016 \\
\hline \multicolumn{5}{|l|}{ PSM Epanechnikov kernel } \\
\hline Senai technical & $\begin{array}{c}0.0402 \\
(0.0613)\end{array}$ & $\begin{array}{c}0.0758 \\
(0.0477)\end{array}$ & $\begin{array}{l}-0.0280 \\
(0.0359)\end{array}$ & $\begin{array}{c}-0.1182^{* *} \\
(0.0511)\end{array}$ \\
\hline Sesi high-school & $\begin{array}{c}0.0256 \\
(0.0594)\end{array}$ & $\begin{array}{c}0.0364 \\
(0.0462)\end{array}$ & $\begin{array}{c}0.0387 \\
(0.0336)\end{array}$ & $\begin{array}{c}0.0417 \\
(0.0494)\end{array}$ \\
\hline Mean dep. var - control group & 0.5601 & 0.6860 & 0.8560 & 0.4591 \\
\hline Coeff. equality test ( $\mathrm{T}$ test - p-value) & 0.586 & 0.065 & 0.000 & 0.000 \\
\hline Observations & 1598 & 2044 & 2054 & 2057 \\
\hline \multicolumn{5}{|l|}{ OLS } \\
\hline Senai technical & $\begin{array}{c}0.0314 \\
(0.0536)\end{array}$ & $\begin{array}{c}0.0176 \\
(0.0406)\end{array}$ & $\begin{array}{l}-0.0191 \\
(0.0316)\end{array}$ & $\begin{array}{c}0.0158 \\
(0.0330)\end{array}$ \\
\hline Sesi high-school & $\begin{array}{c}0.0521 \\
(0.0509)\end{array}$ & $\begin{array}{c}0.0277 \\
(0.0388)\end{array}$ & $\begin{array}{c}0.0070 \\
(0.0295)\end{array}$ & $\begin{array}{c}0.0140 \\
(0.0323)\end{array}$ \\
\hline Mean dep. var - control group & 0.5478 & 0.7195 & 0.8503 & 0.3473 \\
\hline Coeff. equality test ( $\mathrm{T}$ test - p-value) & 0.501 & 0.676 & 0.151 & 0.929 \\
\hline Observations & 1762 & 2259 & 2270 & 2273 \\
\hline $\begin{array}{l}\text { Significance levels: } * 10 \%,{ }^{*} 5 \%, * * * 1 \% \text {. We use } \\
\text { variables, and also the shares observed in the contr } \\
\text { indicates if the individuals are employed in their pref } \\
\text { dummies that equal } 1 \text { if the individuals are satisfied } \\
\text { "Enrolled in Higher Education" is a dummy variabl } \\
\text { degree or postgraduate education. We report our ba } \\
\text { sample, the results using a Epanechnikov kernel mat } \\
\text { (without any selection). When using the propensity } \\
\text { with a caliper of } 2 p . p ., \text { and, after the final sample is } \\
\text { average outcome variable weighting according to each }\end{array}$ & $\begin{array}{l}\text { tred activity SE } \\
\text { ith their profes } \\
\text { that indicates } \\
\text { seline results us } \\
\text { ching to select }\end{array}$ & $\begin{array}{l}\text { d errors. The colur } \\
\text { ted of outsiders. " } \\
\text { ctor. "Professional } \\
\text { sional status and wi } \\
\text { if someone is enrol } \\
\text { ing a nearest neighl } \\
\text { the sample, and a } \\
\text { we first select our }\end{array}$ & $\begin{array}{l}\text { nns display the resu } \\
\text { Activity Sector" is } \\
\text { Status" and "Educa } \\
\text { th their education ba } \\
\text { led in higher educa } \\
\text { oor propensity score } \\
\text { direct OLS that inc } \\
\text { sample using the p } \\
\text { ference between the }\end{array}$ & $\begin{array}{l}\text { lts for different binary } \\
\text { a dummy variable that } \\
\text { tional Background" are } \\
\text { ackground, respectively, } \\
\text { tion, such as bachelors } \\
\text { matching to select our } \\
\text { ludes the whole sample } \\
\text { ropensity score method } \\
\text { groups in terms of the }\end{array}$ \\
\hline
\end{tabular}




\section{Appendix A - Tables}

Table A1: Difference in the average school variables between Sesi and other high schools - 2017 Census

\begin{tabular}{|c|c|c|c|c|c|c|c|c|}
\hline & \multicolumn{2}{|c|}{$\begin{array}{c}\text { Public Paraná } \\
(1)\end{array}$} & \multicolumn{2}{|c|}{$\begin{array}{c}\text { Private Paraná } \\
\text { (2) }\end{array}$} & \multicolumn{2}{|l|}{$\begin{array}{c}\text { Sesi } \\
(3)\end{array}$} & \multicolumn{2}{|c|}{ Testing the mean differences } \\
\hline & Mean & Obs & Mean & Obs & Mean & Obs & $(1)-(3)$ & $(2)-(3)$ \\
\hline The school has: & & & & & & & & \\
\hline School director office & 0.9069 & 1299 & 0.9888 & 356 & 0.9811 & 53 & $-0.0743^{*}$ & 0.0076 \\
\hline School professor office & 0.9638 & 1299 & 0.9944 & 356 & 0.9811 & 53 & -0.0173 & 0.0132 \\
\hline Computer lab & 0.8907 & 1299 & 0.736 & 356 & 0.9623 & 53 & $-0.0716^{*}$ & $-0.2263^{* * *}$ \\
\hline Science lab & 0.7313 & 1299 & 0.9242 & 356 & 0.9057 & 53 & $-0.1743^{* * *}$ & 0.0185 \\
\hline Library & 0.9292 & 1299 & 0.9803 & 356 & 1 & 53 & $-0.0708^{* *}$ & -0.0197 \\
\hline Reading room & 0.0508 & 1299 & 0.5056 & 356 & 0.3019 & 53 & $-0.2511^{* * *}$ & $0.2037^{* * *}$ \\
\hline Auditorium & 0.1339 & 1299 & 0.4972 & 356 & 0.5283 & 53 & $-0.3944^{* * *}$ & -0.0311 \\
\hline Number of classrooms & 11.659 & 1299 & 22.2388 & 356 & 10.3019 & 53 & $1.3571^{*}$ & $11.9369^{* * *}$ \\
\hline Number of used classrooms & 10.4426 & 1299 & 20.3062 & 356 & 8.1321 & 53 & $2.3106^{* * *}$ & $12.1741^{* * *}$ \\
\hline Number of computers & 28.1647 & 1299 & 46.0899 & 356 & 38.9811 & 53 & $-10.8164^{* * *}$ & 7.1088 \\
\hline Number of computers available for students & 19.9761 & 1299 & 28.0927 & 356 & 31.5472 & 53 & $-11.5710^{* * *}$ & -3.4545 \\
\hline Has internet & 0.9931 & 1299 & 0.9944 & 356 & 0.9811 & 53 & 0.0119 & 0.0132 \\
\hline Has high speed internet & 0.8075 & 1299 & 0.9719 & 356 & 0.9623 & 53 & $-0.1547^{* * *}$ & 0.0096 \\
\hline Number of students & 200.3087 & 1299 & 126.3202 & 356 & 175.3962 & 53 & 24.9125 & $-49.0760 * *$ \\
\hline Number of professors & 22.3272 & 1299 & 16.0702 & 356 & 15.283 & 53 & $7.0442^{* * *}$ & 0.7872 \\
\hline
\end{tabular}


Table A2: Difference in the average school variables between Senai and other technical courses - 2017 Census

\begin{tabular}{|c|c|c|c|c|c|c|c|c|}
\hline & \multicolumn{2}{|c|}{$\begin{array}{c}\text { Public Paraná } \\
\text { (1) }\end{array}$} & \multicolumn{2}{|c|}{$\begin{array}{c}\text { Private Paraná } \\
(2)\end{array}$} & \multicolumn{2}{|c|}{$\begin{array}{c}\text { Senai } \\
(3)\end{array}$} & \multicolumn{2}{|c|}{ Testing the mean differences } \\
\hline & Mean & Obs & Mean & Obs & Mean & Obs & $(1)-(3)$ & $(2)-(3)$ \\
\hline The school has: & & & & & & & & \\
\hline School director office & 0.9792 & 48 & 0.989 & 91 & 0.925 & 40 & 0.0542 & $0.0640^{*}$ \\
\hline School professor office & 0.9792 & 48 & 0.978 & 91 & 0.95 & 40 & 0.0292 & 0.028 \\
\hline Computer lab & 1 & 48 & 0.9231 & 91 & 0.975 & 40 & 0.025 & -0.0519 \\
\hline Science lab & 0.7708 & 48 & 0.2857 & 91 & 0.375 & 40 & $0.3958^{* * *}$ & -0.0893 \\
\hline Library & 0.9792 & 48 & 0.967 & 91 & 0.975 & 40 & 0.0042 & -0.008 \\
\hline Reading room & 0.3542 & 48 & 0.5495 & 91 & 0.275 & 40 & 0.0792 & $0.2745^{* * *}$ \\
\hline Auditorium & 0.5833 & 48 & 0.5714 & 91 & 0.625 & 40 & -0.0417 & -0.0536 \\
\hline Number of classrooms & 13.9792 & 48 & 16.8132 & 91 & 15.9 & 40 & -1.9208 & 0.9132 \\
\hline Number of used classrooms & 10.2917 & 48 & 14.7363 & 91 & 14.25 & 40 & $-3.9583^{* *}$ & 0.4863 \\
\hline Number of computers & 85.125 & 48 & 77.7582 & 91 & 72.625 & 40 & 12.5 & 5.1332 \\
\hline Number of computers available for students & 61.9792 & 48 & 39.7802 & 91 & 53.5 & 40 & 8.4792 & -13.7198 \\
\hline Has internet & 1 & 48 & 1 & 91 & 0.975 & 40 & 0.025 & 0.025 \\
\hline Has high speed internet & 0.875 & 48 & 0.956 & 91 & 0.9 & 40 & -0.025 & 0.056 \\
\hline Number of students & 187.1042 & 48 & 151.5934 & 91 & 214.475 & 40 & -27.3708 & -62.8816 \\
\hline Number of professors & 20.2083 & 48 & 15.5495 & 91 & 17.875 & 40 & 2.3333 & -2.3255 \\
\hline
\end{tabular}

Significance levels: $* 10 \%, * * 5 \%, * * * 1 \%$. 


\section{Appendix B - Questionnaire}

\section{PARANÁ \\ PESQUISAS}

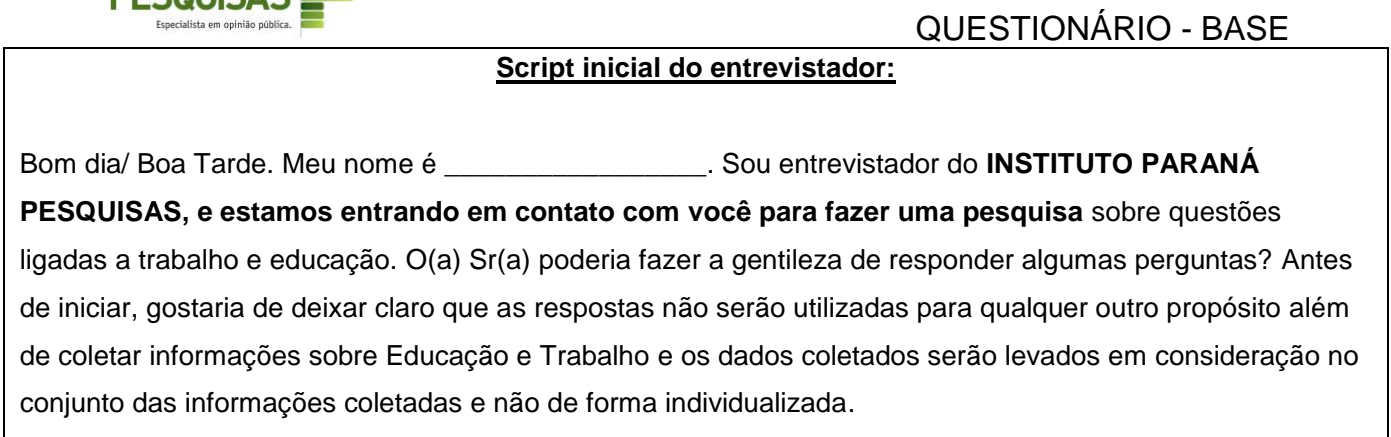

Questões Filtro:
1) Sem escolaridade/ analfabeto (Agradecer e encerrar)
2) Ensino Fundamental Incompleto
3) Ensino Fundamental Completo
4) Ensino Médio Incompleto
5) Ensino Médio Completo
6) Ensino Superior Incompleto
7) Ensino Superior Completo
8) Pós-Graduação ou mais
F2. O(A) Sr(a) estudou ou estuda em alguma unidade do Sistema Fiep, ou seja, alguma Unidade do Senai, Sesi ou IEL?
1) Sim (Exceto perguntas exclusivas do Grupo Controle)
2) Não (Todas as perguntas)
F3. Apenas para os que são egressos dos cursos de Educação do Sistema Fiep: Qual o ano que o(a) Sr(a) concluiu/ terminou os seus
estudos na Unidade do Sistema Fiep?
1) Anterior a 2015 (Agradecer e encerrar)
2) 2015
3) 2016
4) 2017
5) 2018 ou mais (Agradecer e encerrar)

1. Sexo: (Registrar)
1) Masculino
2) Feminino

2. Qual a sua idade? (Registrar a faixa correspondente)
1) 16 a 24 anos
2) 25 a 34 anos
3) 35 ou mais

3. Diga-me, por favor, qual das seguintes situações se aplica melhor ao seu estado civil atual: (Ler as alternativas)
1) Solteiro(a)
3) Divorciado(a)
5) Outro. Especifique:
2) Casado(a)
4) Viúvo(a) 


\section{PARANÁ}

4. Atualmente o(a) $\operatorname{Sr}(a)$ diria que é: (Ler as alternativas)

1) Pessoa responsável pelo seu domicílio

2) Cônjuge/ companheiro(a) do(a) responsável pelo domicílio

3) Filho(a) do(a) responsável pelo domicílio

4) Neto(a) do(a) responsável pelo domicílio

5) Irmão(ã) do(a) responsável pelo domicílio

6) Outro. Especifique:

5. Contando com o(a) $\operatorname{Sr}(a)$, quantas pessoas, incluindo crianças vivem habitualmente em sua residência?

6. De uma maneira geral, o $\operatorname{Sr}(a)$ diria que está muito satisfeito(a), satisfeito(a), nem satisfeito(a), nem insatisfeito(a), insatisfeito(a) ou muito insatisfeito(a) com a sua situação profissional?
1) Muito Satisfeito(a)
4) Insatisfeito(a)
2) Satisfeito(a)
5) Muito insatisfeito(a)
3) Nem Satisfeito(a), Nem Insatisfeito(a)
6) Não sabe/ não opinou (não ler, nem estimular)

7. De uma maneira geral, o $\operatorname{Sr}(a)$ diria que está muito satisfeito(a), satisfeito(a), nem satisfeito(a), nem insatisfeito(a), insatisfeito(a) ou muito insatisfeito(a) com a sua formacão escolar?
1) Muito Satisfeito(a)
4) Insatisfeito(a)
2) Satisfeito(a)
5) Muito insatisfeito(a)
3) Nem Satisfeito(a), Nem Insatisfeito(a)
6) Não sabe/ não opinou (não ler, nem estimular)

8. Qual o Setor que o(a) $\operatorname{Sr}(a)$ acredita que traz mais benefícios para o trabalhador: Serviços, Comércio, Indústria ou Agricultura?
1) Agricultura (ir p/a 10)
2) Comércio (ir p/a 10)
3) Indústria
4) Serviços (ir p/a 10)
5) Não sabe/ não opinou (não ler, nem estimular) (ir p/a 10)

9. Qual desses setores industrias $\circ \operatorname{Sr}(\mathrm{a})$ acredita que traga mais benefícios para o trabalhador? (Ler as alternativas)
1) Não sabe (não ler)
6) Eletro eletrônica
2) Extração mineral (mineração e petróleo)
7) Máquinas e equipamentos
3) Alimentos, Bebidas ou Fumo
8) Veículos
4) Têxtil, vestuário, calçados e couro
9) Construção
5) Química
10) Outro. Especifique 


\section{PARANÁ \\ PESQUISAS}

QUESTIONÁRIO - BASE

10.Qual a sua situação profissional principal, ou seja, a situação da atividade profissional que consome mais tempo de trabalho? (Ler as alternativas)

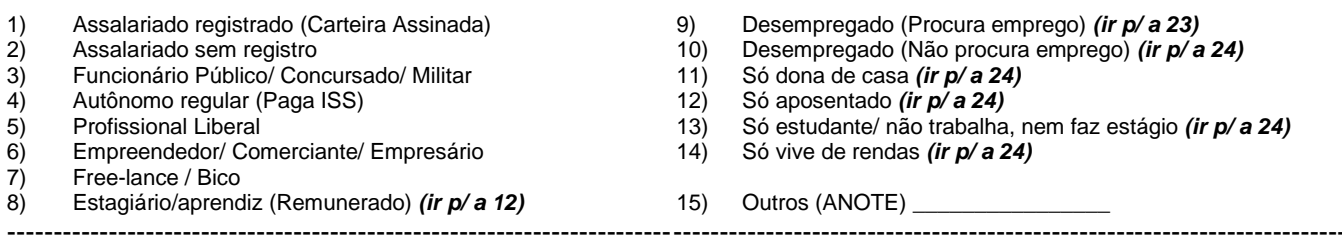

\section{Exceto para Estagiário/ aprendiz}

11.Atualmente o(a) $\mathrm{Sr}($ a) exerce um cargo de Gerente, Coordenador(a), Analista ou Auxiliar/ Assistente?
1) Gerente
3) Analista
5) Outro. Especifique:
2) Coordenador(a)
4) Auxiliar/ Assistente

12. Quanto tempo o $\operatorname{Sr}(a)$ passou procurando esse emprego/ trabalho/ essa ocupação profissional? (Ler as alternativas)
1) Não lembra (não ler)
5) Entre 7 e 9 meses
2) Menos de 1 mês
6) Entre 10 meses e menos de 1 ano
3) Entre 1 e 3 meses
7) 1 ano ou mais
4) Entre 4 e 6 meses

13. Quanto tempo o $\operatorname{Sr}(\mathrm{a})$ está trabalhando nesse emprego? (Ler as alternativas)
1) Não lembra (não ler)
4) Entre 4 e 6 meses
6) Entre 10 meses e menos de
2) Menos de 1 mês
5) Entre 7 e 9 meses
1 ano
3) Entre 1 e 3 meses
7) 1 ano ou mais

14. Nos últimos 12 meses o $\mathrm{Sr}(\mathrm{a})$ foi promovido no seu trabalho, ou seja, teve uma promoção de cargo ou aumento de salário no último ano?
1) Não
2) $\operatorname{Sim}$

15. Qual o seu rendimento mensal com o seu trabalho principal? (Ler as alternativas)
1) Até $R \$ 1.000$
4) Entre $R \$ 3.001$ e $R \$ 4.000$
7) Recusou responder (não ler)
2) Entre $R \$ 1.001$ e $R \$ 2.000$
5) Entre $R \$ 4.001$ e $R \$ 5.000$
3) Entre $R \$ 2.001$ e $R \$ 3.000$
6) Mais de $\mathrm{R} \$ 5.000$

16.Em qual segmento o $\mathrm{Sr}$ (a) trabalha: Indústria, Comércio, Serviços ou Agricultura? (RM)
1) Indústria
3) Serviços (ir p/a 18)
2) Comércio (ir $p / a$ 18)
4) Agricultura (ir $p / a$ 18) 


\section{PARANÁ \\ PESQUISAS}

17.Em que setor Industrial o $\mathrm{Sr}(\mathrm{a})$ trabalha? (RM) (Ler as alternativas)

\section{QUESTIONÁRIO - BASE}
1) Não sabe (não ler)
2) Extração mineral (mineração e petróleo)
3) Alimentos, Bebidas ou Fumo
4) Têxtil, vestuário, calçados e couro
5) Química

6) Eletro eletrônica

7) Máquinas e equipamentos

8) Veículos

9) Construção

10) Outro. Especifique

18.De uma maneira geral, o $\operatorname{Sr}(a)$ diria que está muito satisfeito(a), satisfeito(a), nem satisfeito(a), nem insatisfeito(a), insatisfeito(a) ou muito insatisfeito(a) em trabalhar no Setor (repetir o segmento em que o entrevistado trabalha: Comércio/ Serviço/ Indústria/ Agricultura)?
1) Muito Satisfeito(a)
4) Insatisfeito(a)
2) Satisfeito(a)
5) Muito insatisfeito(a)
3) Nem Satisfeito(a), Nem Insatisfeito(a)
6) Não sabe/ não opinou (não ler, nem estimular)

19. Se o(a) $\operatorname{Sr}($ a) pudesse ou tivesse oportunidade o(a) $\operatorname{Sr}(a)$ trocaria o Setor em que o(a) $\operatorname{Sr}(a)$ trabalha para trabalhar em outro setor, ou seja, o(a) $\mathrm{Sr}(\mathrm{a})$ deixaria de trabalhar no (repetir o segmento em que o entrevistado trabalha: Comércio/ Serviço/ Indústria/ Agricultura) para trabalhar em outro setor? (Caso o entrevistado diga que trocaria, especificar o setor em que gostaria de trabalhar)
1) Não trocaria de setor
3) Sim, trocaria pelo Setor de Serviços
2) Sim, trocaria pelo o Setor Industrial
4) Sim, trocaria pelo Setor Agrícola
2) Sim, trocaria pelo o Setor de Comércio

20.O(a) $\mathrm{Sr}(\mathrm{a})$ exerce tem alguma outra atividade remunerada?
1) Não (ir p/a 24)
2) $\operatorname{Sim}$

21.Essa sua outra atividade remunerada, é no Setor da: Indústria, Comércio, Serviços ou Agricultura? (RM)
1) Indústria
3) Serviços
2) Comércio
4) Agricultura

22. Qual o seu rendimento mensal com essa sua outra atividade remunerada? (Ler as alternativas)
1) Até $R \$ 1.000(p / 24)$
5) Entre $R \$ 4.001$ e $R \$ 5.000(p / 24)$
2) Entre $R \$ 1.001$ e $R \$ 2.000(p / 24)$
6) Mais de $R \$ 5.000(p / 24)$
3) Entre $R \$ 2.001$ e $R \$ 3.000(p / 24)$
7) Recusou responder (não ler) ( $p / 24)$
4) Entre $R \$ 3.001$ e $R \$ 4.000(\boldsymbol{p} / \mathbf{2 4})$ 


\section{PARANÁ \\ PESQUISAS}

23. Qual o principal motivo que o(a) $\operatorname{Sr}($ a) atribui para o fato de ainda não ter conseguido uma colocação profissional? (Ler as alternativas)

1) O mercado de trabalho está difícil

2) Não tenho os conhecimentos técnicos necessários para conseguir uma vaga

3) Não tenho as habilidades práticas necessárias para conseguir uma vaga

4) Não tenho o perfil pessoal necessário para conseguir uma vaga

5) Outro. Especifique:

24.O $\operatorname{Sr}(a)$ estudou ou estuda na modalidade Regular ou na modalidade de Educação de Jovens e Adultos/ Supletivo/ CEBEJA?

1) Estudou na modalidade regular

2) Educação de Jovens e Adultos/ Supletivo/ CEBEJA

25.A maior parte dos seus estudos foi feita em Instituições Privadas ou Públicas?

1) Instituições Privadas

2) Instituições Públicas

26. Atualmente o $\operatorname{Sr}($ a) está estudando?

1) Não (Verificar se a escolaridade é superior ou mais, em caso positivo, ir para a 28, em caso negativo, ir para a 30)

2) $\operatorname{Sim}$

27. Atualmente o $\mathrm{Sr}(\mathrm{a})$ está cursando o ensino fundamental, médio regular, médio técnico, graduação, pósgraduação, ou algum curso de qualificação profissional?
1) Ensino Fundamental (ir $p / 30$ )
4) Graduação
2) Ensino Médio regular (ir $\boldsymbol{p} / \mathbf{3 0}$ )
5) Pós-graduação
3) Ensino Médio técnico (ir $p / 30$ )
6) Algum curso de qualificação profissional (ir p/ 30)

Para os que já possuem ensino superior ou estão cursando a graduação ou pós-graduação:

28. Qual a área do curso superior que o(a) $\operatorname{Sr}(a)$ está cursando/ cursou? (ESPONTÂNEA)

Para os que já possuem ensino superior ou estão cursando a graduação ou pós-graduação:

29. Em que ano o(a) $\mathrm{Sr}$ (a) concluirá/ concluiu o Ensino Superior? (ESPONTÂNEA)

Pensando em cursos de Capacitação/ Qualificação Profissional, gostaria que o(a) Sr(a) dissesse se considera extremamente importante, muito importante, importante, pouco importante ou sem importância cada um dos itens que the vou ler.
1) Extremamente importante
4) Pouco importante
2) Muito importante
5) Sem importância
3) Importante
6) Não sabe/ não opinou (não ler, nem estimular)

30. Reputação da Instituição que oferta o curso

31. Conhecimento e formação dos Professores 


\section{PARANÁ \\ PESQUISAS}

32. Relacionamento entre Professores e alunos

33. Instalações físicas da Instituição que oferta os cursos

34.Ambiente entre os alunos/ companheirismo

35. Forma de ensinar/ didática das aulas

36.Variedade de cursos ofertados pela Instituição

37.Saídas profissionais/ estágios ofertados

\section{QUESTIONÁRIO - BASE}

38.Nos últimos 2 anos, o(a) $\operatorname{Sr}(a)$ participou de algum curso/ treinamento profissional?
1) Não (ir p/a 40)
2) $\operatorname{Sim}$

39. Qual foi a área desse curso/ treinamento que o(a) $\operatorname{Sr}(a)$ participou? (Ler as alternativas)
1) Não se recorda (não ler)
4) Construção Civil
7) Mecatrônica
2) Gestão
5) Alimentos e Bebidas
8) Outro. Especifique
3) Tecnologia da Informação
6) Segurança no Trabalho

40.Quais dos seguintes conhecimentos técnicos o(a) $\operatorname{Sr}(a)$ acredita que são muito importantes para o sucesso na ocupação profissional que o(a) $\mathrm{Sr}(\mathrm{a})$ tem /pretende ter? (RM) (Ler as alternativas)
1) Não sabe (não ler)
4) Gestão Financeira
7) Mecânica de automóveis
2) Matemático/ quantitativo
5) Gestão de pessoas
8) Outros, especificar:

41. Quais das seguintes habilidades práticas o(a) $\operatorname{Sr}(a)$ acredita que são muito importantes para o sucesso na ocupação profissional que o(a) $\operatorname{Sr}(a)$ tem /pretende ter? (RM) (Ler as alternativas)
1) Não sabe (não ler)
8) Liderança
2) Comunicação escrita
9) Gestão de pessoas e processos
3) Comunicação verbal
10) Negociação
4) Conhecimento do negócio
11) Organização
5) Cumprimento de metas
12) Planejamento
6) Flexibilidade
7) Trabalho em equipe
13) Outros, especificar:

42. Quais das seguintes atitudes o(a) $\operatorname{Sr}(a)$ acredita que são muito importantes para o sucesso na ocupação profissional que o(a) $\mathrm{Sr}(\mathrm{a})$ tem /pretende ter? (RM) (Ler as alternativas)
1) Não sabe (não ler)
8) Entusiasmo
2) Agilidade
9) Equilíbrio emocional
3) Criatividade
10) Foco nos resultados
4) Disponibilidade
11) Saber ouvir
5) Empatia
12) Tomar decisões
6) Ética
7) Empreendedorismo
13) Outros, especificar: 


\section{PARANÁ

43. De uma maneira geral o(a) $\operatorname{Sr}(a)$ diria que Ihe faltam mais conhecimentos técnicos, habilidades práticas ou competências interpessoais para ter mais sucesso na sua vida profissional?
1) Não sabe (não ler, nem estimular)
4) Habilidades práticas (saber fazer)
2) Nada (não ler, nem estimular)
5) Competências interpessoais
3) Conhecimentos técnicos (saber como fazer)
6) Outro. Especifique:

44.O(A) Sr(a) pretende, nos próximos 2 anos, fazer algum curso/ treinamento para desenvolver essas competências?
1) Não (ir p/a 46)
2) $\operatorname{Sim}$

45.Qual a área desse curso/ treinamento que o(a) $\operatorname{Sr}(a)$ pretende/ gostaria de fazer? (RM) (Ler as alternativas)
1) Não sabe (não ler)
10) Energia
19) Química
2) Alimentos e bebidas
11) Gestão
20) Refrigeração e climatização
3) Automação
12) Gráfica e editorial
21) Segurança no trabalho
4) Automotiva
13) Logística
22) Tecnologia da informação
5) Celulose e papel
14) Madeira e mobiliário
23) Telecomunicações
6) Construção
15) Meio ambiente
24) Têxtil e vestuário
7) Couro e calçados
16) Metalmecânica
8) Educação
17) Metrologia
25) Outro. Especifique
9) Eletroeletrônica
18) Polímeros (borracha e plástico)

\section{Apenas para os Não Egressos:}

46.O(A) $\operatorname{Sr}(a)$ conhece ou já ouviu falar nos cursos do Sesi/ Senai ou IEL?
1) Não (ir p/a 49)
2) $\mathrm{Sim}$

\section{TODOS}

47.De uma maneira geral, a imagem que o(a) Sr(a) tem dos cursos do Sesi/ Senai/ IEL é ótima, boa, regular, ruim ou péssima?
1) Ótima
3) Regular
5) Péssima
2) Boa
4) Ruim
6) Não sabe/ não opinou (não ler)

48. Nos próximos 2 anos, o(a) $\operatorname{Sr}(a)$ diria que há uma possibilidade muito alta, alta, nem alta, nem baixa, baixa ou muito baixa que o(a) Sr(a) venha a fazer algum dos cursos do Sesi/ Senai/ IEL?
1) Muito alta
3) Nem alta, nem baixa
5) Muito baixa
2) Alta
4) Baixa
6) Não sabe/ não opinou (não ler) 


\section{PARANÁ}

\section{PESQUISAS}

49. Dados de contato.

Nome:

Bairro:

Email:

Telefone de contato:

\section{QUESTIONÁRIO - BASE}

